Chapter 10

\title{
HLA and Infectious Diseases
}

\author{
Daniela Maira Cardozo, \\ Amanda Vansan Marangon, Ana Maria Sell, \\ Jeane Eliete Laguila Visentainer and \\ Carmino Antonio de Souza \\ Additional information is available at the end of the chapter \\ http://dx.doi.org/10.5772/57496
}

\section{Introduction}

The Human Leukocyte Antigen (HLA) system is the Major Histocompatibility Complex (MHC) in humans, and all knowledge on this system is of great interest to the field of medical sciences. HLA has become an important tool for understanding the pathogenesis of various infectious diseases; the alleles or HLA haplotypes inherited by an individual can predict several risk and protective factors related to infections caused by various agents.

The list of infectious diseases associated with the HLA system is constantly increasing and the level of association is quite variable. New classification methods and frequent nomenclature updates have facilitated the understanding of the role of polymorphisms in this system and the association with various diseases.

The purpose of this chapter is to show the genetic variability of HLA genes and its influence in the immunopathogenesis of diseases caused by different classes of pathogens. The first part of the chapter encompasses aspects of the structure and function of MHC genes and the role of the molecules encoded by these genes. Subsequently, we present some infectious diseases associated with the HLA system that have been highlighted in the global overview.

\section{Structure and function of the HLA}

MHC is divided into three main regions and has over 200 genes, most of which have functions related to immunity, and are contained within $4.2 \mathrm{Mbp}$ of DNA on the short arm of chromo- 
some 6 at 6 p21.3 [1]. In the HLA Class I region, near to the telomere, are located the HLA-A, $B$ and $-C$ classic genes and $-E,-F$ and $-G$ non-classic genes, among other genes and pseudogenes. The HLA Class II region, near to centromere, contains HLA-DR, -DQ and -DP genes. Subregion DR includes DRA gene which codes for the low-polymorphic alpha-chain and can combine with any beta chains codifying for DRB genes [2]. The Class III region, located between class I and II region contains the C2, C4A, C4B and B genes, that code for complement proteins and tumor necrosis factor (TNF) [1,2].

HLA molecules are polymorphic membrane glycoproteins found on the surface of nearly all cells. Multiple genetic loci within MHC encode these proteins, and one individual expresses simultaneously several polymorphic forms from a large pool of alleles in the population. The overall structure of the HLA class I and class II molecules is similar, with most of the polymorphisms located in the peptide binding groove, where there is the antigens recognized [3].

Class I molecules are composed of one heavy chain $(45 \mathrm{kD})$ encoded within the MHC and a light chain called $\beta 2$-microglobulin (12kD) whose gene is on chromosome 15 . Class II molecules consist of one $\alpha(34 \mathrm{kD})$ and one $\beta$ chain (30kD) both coding within MHC [1]

The class I heavy chain has three domains of which the membrane-distal first $(\alpha 1)$ and the second $(\alpha 2)$ are the polymorphic ones. These polymorphic domains concentrate three regions: positions 62 to $83 ; 92$ to 121 ; and 135 to 157 . These areas are called hypervariable regions. The two polymorphic domains are encoded by exons 2 and 3 of the class I gene. The diversity in these domains is of great importance as this is where the two domains that form the antigen binding cleft $(\mathrm{ABC})$ or peptide binding groove (PBG) of MHC class I molecule are located [4,5]. The sides of the antigen-binding cleft are formed by $\alpha$ helices, whereas the floor of the cleft is comprised of eight anti-parallel beta sheets. The antigenic peptides of eight to ten amino acids (typically nonamers) bind to the cleft with low specificity but high stability. The $\alpha_{3}$ domain contains a conserved seven amino acid loop (positions 223 to 229), which serves as a binding site for CD8 [3,6-8].

Class II molecules comprised of two transmembrane glycoproteins: $\alpha$ and $\beta$ chains, are restricted to the cells of the immune system (e.g. B cells, dendritic cells), but may also be induced on other cells during immune response. The PBG of class II molecules has open ends which allow the peptide to extend beyond the groove at both ends, and therefore to be longer (12-24 amino acids). The peptide is presented to CD4 T-cells [1]. Both $\alpha$ and $\beta$ chains are usually polymorphic in class II molecules. In these chains, the $\alpha 1$ and $\beta 1$ domains are of the PBG and therefore diversity is found mainly in these domains, which are encoded by the exon 2 of their class II A or B genes and the hypervariable regions tend to be found in the groove walls [7].

T cell activation occurs following recognition of peptide / MHC complexes on an antigenpresenting cell (APC). T cell activation can be viewed as a series of intertwined steps, ultimately resulting in the ability to secrete cytokines, replicate, and perform various effector functions. During antigen presentation, the antigen receptors of T cells (TCR) recognize both the antigen peptide and the MHC molecules, with the peptide being responsible for the fine specificity of antigen recognition and MHC residues contributes for the restriction of the T cells (CD4 and 
CD8). During antigen presentation, CD4 and CD8 are intimately associated with the TCR and bind to the MHC molecule [9].

\section{Haplotype, linkage disequilibrium and HLA genes expression}

HLA genes are transmitted for Mendel segregation and allelic variant is expressed in a codominant mode. The set of HLA alleles present in each chromosome of the pair is denominated haplotype. The probability of a sibling having the same HLA haplotype as the other is $25 \%$, different haplotypes is $25 \%$ and $50 \%$ are share only one haplotype [2].

Moreover, there is a fact that occurs in HLA genes called linkage disequilibrium which denotes that certain alleles occur together with a greater frequency than would be expected by chance (non-random gametic association). Variations in the expected combinations of alleles in the population, more often or less often than would be expected from a random formation of haplotypes from alleles, could be related to linkage disequilibrium [1]. For example, a determined population has a gene frequency of $14 \%$ for $H L A-A^{*} 01$ and $9 \%$ for $H L A-B^{*} 08$, therefore the expected frequency for this haplotype would be $1.26 \%(0.14 \times 0.09)$, the actual frequency is however, $8.8 \%$ in this population, a higher frequency than expected, characterizing a positive linkage disequilibrium [2].

\section{HLA and infection diseases}

The frequency and the presence of HLA alleles vary among different populations. Studies suggest that the alleles that can confer resistance to certain pathogens are prevalent in areas with endemic diseases. Furthermore, genomic analysis in families has helped to map and identify the loci related to a number of diseases. Moreover, a number of diseases have been mapped and had their related loci identified thanks to the genomic analysis of families.

\subsection{Bacterial diseases}

\subsubsection{Tuberculosis and leprosy}

Leprosy and tuberculosis (TB) have afflicted humanity since time immemorial, and a number of factors converge to a timely discussion on mycobacterial disease. These factors include the re-emergence of human tuberculosis in epidemic proportions on a global scale, and the special position of leprosy among communicable diseases, the frequency of disabilities, and the social and economic consequences of these diseases.

The immunological mechanism involved in the breakdown of host resistance in these individuals remains unclear. A better understanding of the mechanisms that lead to the protective immunity of the host is fundamental in order to develop novel therapies and vaccines. 
Cell-mediated immunity is thought to be the major component of host defense against mycobacterium; consequently, the induction of optimal Th1 response is protective immunity against mycobacterial infection.

Whereas exposure to and infection by $M$. leprae are necessary to acquire the disease, heritable factors are equally important in determining who will eventually develop clinical signs of leprosy. Numerous studies that have recently been reviewed support the major role of host genetic factors in the large variability of the host response to bacillus infection.

The extensive polymorphism of the class II genes and molecules results in genetically controlled interindividual differences in antigen-specific immune responsiveness, which in turn may lead to differential susceptibility to or expression of disease. The induction of cytolytic CD4+ Th1-like cells during mycobacterial infections has been extensively documented [10,11] Thus, under inflammatory conditions it would be conceivable for T cells to access Schwann cells and recognize the HLA/peptide complexes presented by the Schwann cell.

\subsubsection{HLA and leprosy}

Leprosy is a chronic infection disease caused by Mycobacterium leprae (M. leprae) (Hansen, 1874), an intracellular parasite of macrophages, with high infectivity and low pathogenicity, which primarily affects the peripheral nerves and the skin [12]. The contact with $M$. leprae occurs mainly through the superior aerial views, but may also occur through the skin and maternal milk. A long period of exposure to the microorganism, between 2 and 5 years, is needed to promote the infection [13].

A global increase in both prevalence and new case detection has been observed as compared to 2011. The prevalence of leprosy in 2012 was 181,941 (0.34), compared to 189,018 (0.33) at the end of the first quarter of 2013, and approximately, 232,857 new cases reported (4.00/100,000 population), in the population were detected during the year of 2012 [14]. Currently, the major prevalence is in the Southeast Asiatic, South American, and African continents.

In 1966, Ridley and Jopling, based on clinical, histological, and immunological criteria, classified the spectra of leprosy into 5 groups: tuberculoid (TT), borderline-tuberculoid (BT), borderline-borderline (BB), borderline-lepromatous (BL) and lepromatous (LL). The Madrid classification was presented to subdivide leprosy patients into four different types (lepromatous, tuberculoid, borderline, and indeterminate), and since the year of 1998, the World Health Organization has recommended a new classification based on the number of skin lesions: paucibacillary $(\mathrm{PB})$ for patients who have up to five skin lesions (lower bacterial load) and multibacillary $(\mathrm{MB})$ for patients who have six or more skin lesions (higher bacterial load) [15].

The major signals of this disease are hypostatical cutaneous lesions, dilation of peripheral nerves, and the presence of acid-resistant bacillus in the skin lesions [16]. The undetermined form is an initial stage where the clinical and histopathological courses are uncertain. In the TT form, the lesions are maculates or infiltrated and can reappear or develop from undetermined macula, whereas in the LL form there are multiple lesions with numerous bacillus detected by skin biopsies [17]. 
Leprosy has been considered a multifactorial disease; the expression of clinical manifestations reflects the relation between the host and the parasite. The infection evolution depends on to the specific response on behalf of the host to the parasite. There is a good relationship observed in vitro and in vivo between the immunity mediated by cells (CMI) against antigens of $M$. leprae and the course of the disease. In the located and non-severe form TT, an efficient CMI to $M$. leprae develops with low levels of antibodies. On the other side of the leprosy spectrum are polar LL patients, who have a high humoral immune response and a low cellular response. Most patients, however, are between these two poles and are classified as borderline leprosy cases [18].

The susceptibility to M. leprae infection is complex and influenced by several host, parasite, and environmental factors. In 1929, Hopkins and Denny postulated that genetic variability was the basis of family and racial differences regarding the expression and incidence of the disease. Many epidemiologic studies that aimed to identify susceptibility genes have indicated that genetic characteristics of the host play a role in the variability of the clinical response to M. tuberculosis and M. leprae infection [19].

HLA has been studied in several distinctive illnesses, including infectious diseases. HLA alleles codify class I and II crucial molecules for CMI cell interaction. The HLA system participates effectively in the immune response by promoting the interaction between pathogen epitopes and the host cell $\mathrm{T}$ repertory. Consequently, depending on host HLA, different host responses can occur against the same antigen.

Previous investigations demonstrated different class I HLA variants associated to TT and LL forms of leprosy, in several populations. In India, the most important country in number of infected individuals with the bacillus, an important association with leprosy was reported for HLA-B40 antigen and HLA-A2-B40, HLA-A11-B40, and HLA-A24-B40 haplotypes [20]. Further studies in India replicated these findings; HLA-A11 [21] and HLA-B60 (split of B40) [22] antigens were associated to the LL form. Subsequently, with the advent of molecular genotyping, HLA class I alleles were determined in Indian multibacillary leprosy patients, resulting in a positive association with $H L A-A^{*} 02: 06, A^{*} 11: 02, B^{*} 18: 01, B^{*} 51: 10, C^{*} 04: 07$, and $C^{*} 07: 03$ alleles, and a negative association with $C^{*} 04: 11$ [23]. Moreover, the $A^{*} 11-B^{*} 40$ haplotype was confirmed in multibacillary leprosy patients compared to controls [24].

Recent studies have shown a positive association between LD and $H L A-A^{*} 11, H L A-B^{*} 38$, and $H L A-C^{*} 12$, as well as a negative association with $H L A-C^{*} 16$. When groups were stratified, $H L A-$ $B * 35$ and $H L A-C^{*} 04$ were shown to be protective against lepromatous leprosy, whereas $H L A$ $C^{*} 07$ was shown to be a susceptibility variant [25]. Furthermore, the allele HLA-C*15:05 has been related to the LD phenotype in certain populations from India and Vietnam [26].

However, the main restriction determinants for M. leprae seem to reside on DR or DQ molecules. The HLA-DR2 molecule [26-28], later identified as DRB1*15 and DRB1*16 variants, is primarily associated with leprosy or different clinical forms [29-33]. Risk for leprosy associated with $D R B 1^{*} 10$ has been described in Turkish, Vietnamese, and Brazilian populations [30,34], whereas $H L A-D R B 1^{*} 14$ has been associated with the TT group in a population from northeastern Brazil [33] and with leprosy per se in the Argentinean population [35]. 
HLA molecules with the highest affinity to peptide produce the greatest $\mathrm{T}$ cell proliferation and IFN- $\gamma$ response [36], and the peptide presentation by low affinity class II molecules may result in muted cell-mediated immunity [36]. Alternatively, peptide presentation by specific class II molecules may result in activation of suppressor/regulatory T-cells [37]. A protective effect against leprosy has been described for DRB1*04 in Brazilian, Korean, Japanese, Vietnamese, Argentinean, and Taiwanese populations [30,38-40].

In addition to the studies that have been performed to investigate the molecular mechanisms of mycobacterium antigens restricted to HLA, certain Class II HLA genes have been suggested, as the selection of determined groups of antigen peptides and specific T helper cells, can contribute to the development of leprosy polar [41] and also tuberculoses [42].

\subsubsection{HLA and tuberculosis}

Tuberculosis, or TB, is a chronic disease caused by Mycobacterium tuberculosis, considered a major public health problem worldwide. The infection most commonly affects the lungs (Pulmonary Tuberculosis). One-third of the world's population has been in contact with the pathogen, but approximately $90 \%$ of the infected persons do not present clinical symptoms [43].

According to the World Health Organization [14], in 2011, there were an estimated 8.7 million new cases of TB (13\% co-infected with HIV) and 1.4 million people died from TB, including almost one million deaths among HIV-negative individuals and 430,000 among people who were HIV-positive. Among the TB high-burden countries (approximately, 80\% of all new TB cases arising each year), the highest rates of case detection in 2011 were estimated to be in Brazil, China, Kenya, the Russian Federation, and the United Republic of Tanzania.

A great challenge in immunology is to understand the complexities, mechanisms, and consequences of host interactions with microbial pathogens. The innate immune response to intracellular bacteria involves mainly macrophages and natural killing cells (NK). Bacteria activate NK cells directly or stimulate macrophages to produce cytokines that activate NK cells, which results in a broad and fast antimicrobial response critical to the control of pathogen dispersion. Innate immunity can limit bacterium growth for some time, but in general, it does not succeed in eradicating infections, triggering the acquired immunity mainly through cell action.

Proteins are processed by APCs that interact with surface receptors of T-lymphocytes (T CD4+) as peptides associated with class II HLA molecules. Either the phagocyted bacteria are transported from the phagosome to the cytosol or they escape the phagosome and enter the cytoplasm of infected cells, and their degraded products are expressed on the cell surface associated with the HLA molecule, whose complex interacts with the specific cytotoxic T CD8+ receptors. Thus, the $\mathrm{T}$ cell eradicates the target cell. The activation of the macrophage can also result in tissue lesion in the form of late hypersensibility reaction to the protein antigens. Bacteria may resist death within the phagocytes for a long period, producing macrophage and lymphocyte cell infiltration around them and giving rise to granulomes $[44,45]$. 
A number of genes are thought to be important in the pathogenesis of TB [46,47]. HLA class I molecules are involved in antigen presentation to CD8 cytotoxic T-cell response stimulation. However, the participation of these molecules is controversial in tuberculosis. A meta-analysis study reported that subjects carrying HLA-B13 had a lower risk for thoracic TB, whereas other class I antigens could not be related to tuberculosis pathogenesis [48].

Earlier studies revealed that HLA-DR2/DR3, DR2/DR4 and DR2/DR5 are the major heterozygous combinations associated with susceptibility to TB [49]. These same authors have also identified the association of HLA-DRB1 alleles and cytokine secretion in response to live $M$. tuberculosis [50]. An increased IFN- $\gamma$ response in $H L A-D R B 1^{*} 03$-positive and a decreased IFN$\gamma$ response in $H L A-D R B 1^{*} 15$-positive patients, an increased level of IL-12p40 in DRB1*10 and IL-10 in $D R B 1^{*} 12$ positive and an increased level of IL-6 in $D R B 1^{*} 04$ positive patients were observed.

The HLA class II variant, DR2 encoded by DRB1*15 and DRB1*16, is associated with TB in several populations [51,52]. In South Africans [53], a significant interaction between HLA$D R B 1^{*} 13: 02$ allele and susceptibility to TB was observed. A study in Poland [54] related a significant interaction between $H L A-D R B 1^{*} 16$ and $H L A-D R B 1^{*} 14$ and susceptibility to TB. Furthermore $H L A-D R B 1 * 04$ and $H L A-D Q B 1^{*} 02: 01$ were associated with TB in Chinese patients [55].

Hence, whether the presentation of mycobacterial epitopes by HLA molecules is beneficial or detrimental to mounting a protective response to tuberculosis and leprosy conditions has yet to be explored.

\subsection{Viral diseases}

\subsubsection{HLA and dengue}

Dengue is a resurging mosquito-borne disease that is often contracted by US travelers visiting Latin America, Asia, and the Caribbean. The clinical symptoms range from a simple febrile illness, called to Dengue Fever (DF), to hemorrhagic fever represented for Dengue Hemorrhagic Fever (DHF) or shock symptoms, called to Dengue Shock Sindrome (DSS) [56].

Nowadays, there are currently four known serotypes: DEN 1, 2, 3 and 4, which are strongly related. The viruses belong to the genus flavivirus, family Flavaviridae and are prevalent in tropical and sub-tropical regions around the world, predominantly in urban and semi-urban areas [57].

The pathophysiology of DF viral infections and factors that result in severe clinical disease are poorly understood. Cross-reactive memory $\mathrm{T}$ cells and antibodies have been suggested to contribute to the immunopathology by altering the cytokine profiles during secondary infection and are believed to be less effective in eliminating the newly infective virus serotype [58].

However, genetic factors appear to be important in the manifestation of DF as, even in endemic areas, only a small proportion of people develop DF or the most serious forms of the disease. 
During infection by DF virus, a series of genes have their regulation mechanisms modified, among them, genes linked to high production of IFN-gamma, as well as MIP-1 $\beta$, RANTES, MBL2, IL-8 and IL-10 [59,60]. Host genetic polymorphisms involved in innate immune responses have been shown to be correlated with resistance to DHF, such as a variant of the FcGRIIA [61], functional polymorphisms of MBL2 [62], and the polymorphisms the CD209 promoter [63].

Similarly, studies on MHC-encoded transporters associated with antigen processing (TAP) genes have also shown associations with DHF [64, 65]. In addition, the analyses of tumor necrosis factor (TNF) and lymphotoxin alpha (LTA) genes have revealed specific combinations of TNF, LTA, and HLA class I alleles that associate with DHF and production of LTA and TNF [66].

Several aspects of $\mathrm{T}$ cell functionality are altered in DHF patients, including proliferation, activation status, production of cytokines, and their survival [67-70]. All these functions are influenced by specific recognition, through TCRs, of the antigen associated with HLA molecules. Thus, polymorphisms of HLA genes may also play an important role in dengue severity. Several genetic variations in HLA class I alleles have been found to correlate with dengue severity in Southeast Asian populations.

Some studies have revealed positive associations, whereas others have reported negative associations between DF and HLA classes I and II alleles. In Mexico and Cuba, HLA-B*35, $D R B 1^{*} 04,{ }^{*} 07,{ }^{*} 11$, and $D Q B 1{ }^{*} 03: 02$ were associated to protection against classical DF $[12,13]$. Meanwhile in Mexico, Thailand, and Cuban the HLA-A*02:03, *31, $B^{*} 15,{ }^{*} 51,{ }^{*} 52, D Q B 1 * 01$, and ${ }^{*} 02: 02$ have been associated with susceptibility to the classical disease [71,72].

Results based on a study with 85 dengue fever cases, 29 dengue hemorrhagic fever and 110 health controls (HCs) on Western India population, revealed a significantly higher frequency of $H L A-A^{*} 33$ in DF cases compared to HCs, the frequency of $H L A-A^{*} 02: 11$ was higher in DHF cases compared to DF cases. The frequency of $H L A-B^{*} 18$ was significantly higher in dengue (DEN) cases. The frequency of $H L A-C^{*} 07$ was significantly higher in DEN cases. Significance was observed even when the cases were categorized into DF and DHF [73].

The combined frequency of $H L A-C^{*} 07$ with $H L A-D R B 1^{*} 07 /^{*} 15$ genotype was significantly higher in DHF cases compared to DF and HCs. On the other hand, the frequency of combination of $H L A-C^{*} 07$ without $H L A-D R B 1^{*} 07$ was significantly higher in DF cases compared to HCs. The results suggest that $H L A-A^{*} 33$ may be associated with DF whereas $H L A-B^{*} 18$ and $H L A-C^{*} 07$ may be associated with symptomatic dengue requiring hospitalization. In the presence of $H L A-D R B 1^{*} 07 /^{*} 15$ genotype, $H L A-C^{*} 07$ is associated with increased risk of developing DHF whereas in the presence of other HLA-DRB1 alleles, $H L A-C^{*} 07$ is associated with DF [73].

Our group had previously found a strong association between HLA-DQ1 and classical DF, during an epidemic that occurred in a Southern Brazilian population in 1995, characterized by the presence of DF virus serotype 1, however no association between DF and HLA class I antigens was detected [74]. 
The statistical analysis revealed however, an association between $H L A-A^{*} 01$ and DHF in the Brazilian population, whereas analysis of $H L A-A^{*} 31$ suggested a potential protective role in DHF that should be further investigated. This study provides evidence that HLA class I alleles might represent important risk factors for DHF in Brazilian patients. [75].

In addition, HLA class I and II have been associated to primary and the several forms of DF around the world [76]. The host HLA allele profile influenced the reactivity of DF-specific T cells, and may be responsible for the immunopathology of DF infection [77].

\begin{tabular}{|c|c|c|c|c|c|c|}
\hline HLA Allele & Infection & Serotype & Case (n) & Control & Population & Reference \\
\hline \multicolumn{7}{|l|}{ Susceptible } \\
\hline$A^{*} 02: 03$ & 2 nd & DV-1 & DF (49) & 140 & Thai & Stephens et al., 2002 \\
\hline$A^{*} 02: 03$ & $2 n d$ & DV-3 & DF (26) & 140 & Thai & Stephens et al., 2002 \\
\hline$A^{*} 02: 03$ & 2nd & all & DF (106) & 140 & Thai & Stephens et al., 2002 \\
\hline$B * 52$ & 2nd & DV-2 & DF (17) & 140 & Thai & Stephens et al., 2002 \\
\hline$B * 52$ & 2nd & - & DF (106) & 140 & Thai & Stephens et al., 2002 \\
\hline$D Q B 1 * 01$ & - & - & DF (23) & 34 & Mexican & $\begin{array}{l}\text { Falcón-Lezama et. al., } \\
2009\end{array}$ \\
\hline$D Q B 1 * 02: 02$ & - & - & DF (23) & 34 & Mexican & $\begin{array}{l}\text { Falcón-Lezama et. al., } \\
2009\end{array}$ \\
\hline DQ1 & - & - & DF (64) & 64 & Brazilian & Polizel et. al., 2004 \\
\hline $\begin{array}{l}A^{*} 24, \text { codon } 70 \\
\text { histidine }\end{array}$ & - & - & DHF (59) & 200 & Vietnamese & Lan et. al., 2008 \\
\hline $\begin{array}{c}A^{*} 24, \text { codon } 70 \\
\text { histidine }\end{array}$ & - & - & DHF (117) & 250 & Vietnamese & Lan et. al., 2008 \\
\hline$A^{*} 02: 07$ & $2 n d$ & DV-1 & DHF/DSS (32) & 140 & Thai & Stephens et al., 2002 \\
\hline$A^{*} 02: 07$ & 2 nd & DV-2 & DHF/DSS (36) & 140 & Thai & Stephens et al., 2002 \\
\hline$A * 02: 07$ & 2nd & DV-1, DV-2 & DHF/DSS (103) & 140 & Thai & Stephens et al., 2002 \\
\hline$A^{*} 02: 07$ & $2 n d$ & all & DHF/DSS (103) & 140 & Thai & Stephens et al., 2002 \\
\hline$A^{*} 03$ & - & - & DHF/DSS (51) & 95 & $\begin{array}{c}\text { Malay, } \\
\text { Chinese, Indian }\end{array}$ & Appanna et. al., 2010 \\
\hline$B * 13$ & - & - & DHF/DSS (19) & 95 & Malay & Appanna et. al., 2010 \\
\hline$B * 51$ & 2nd & all & DHF/DSS (103) & 140 & Thai & Stephens et al., 2002 \\
\hline$B * 51$ & 2nd & DV-1 & DHF/DSS (32) & 140 & Thai & Stephens et al., 2002 \\
\hline$B * 53$ & - & - & DHF/DSS (51) & 95 & $\begin{array}{c}\text { Malay, } \\
\text { Chinese, Indian }\end{array}$ & Appanna et. al., 2010 \\
\hline
\end{tabular}




\begin{tabular}{|c|c|c|c|c|c|c|}
\hline HLA Allele & Infection & Serotype & Case (n) & Control & Population & Reference \\
\hline$A^{*} 24$ & & & DHF/DSS (309) & 251 & Vietnamese & $\begin{array}{l}\text { Fernández-Mestre et. } \\
\text { al., } 2004\end{array}$ \\
\hline$A^{*} 02$ & $2 n d$ & - & DSS (41) & 138 & Thai & Chiewsilp et. al., 1981 \\
\hline $\begin{array}{c}A^{*} 24, \text { codon } 70 \\
\text { histidine }\end{array}$ & - & - & DSS (152) & 250 & Vietnamese & Lan et. al., 2008 \\
\hline $\begin{array}{c}A^{*} 24, \text { codon } 70 \\
\text { histidine }\end{array}$ & - & - & DSS (170) & 200 & Vietnamese & Lan et. al., 2008 \\
\hline $\begin{array}{c}A^{*} 24, \text { codon } 70 \\
\text { histidine }\end{array}$ & & & DSS (96) & 200 & Vietnamese & Lan et. al., 2008 \\
\hline B blank & 2nd & - & DSS (41) & 138 & Thai & Chiewsilp et. al., 1981 \\
\hline$A^{*} 31$ & - & DV -2 & DF, DHF/DSS (120) & 189 & Cuban & Sierra et. al., 2007 \\
\hline$B * 15$ & - & DV-2 & DF, DHF/DSS (120) & 189 & Cuban & Sierra et. al., 2007 \\
\hline$B * 51$ & 2nd & DV -3 & DF, DHF/DSS (51) & 140 & Thai & Stephens et al., 2002 \\
\hline \multicolumn{7}{|l|}{ Resistant } \\
\hline$D R B 1 * 11$ & - & - & DF (47) & 34 & Mexican & La Fleur et. al., 2002 \\
\hline$D Q B 1 * 03: 02$ & - & - & DF (23) & 34 & Mexican & $\begin{array}{l}\text { Falcón-Lezama et. al., } \\
2009\end{array}$ \\
\hline$D R B 1 * 09: 01$ & $1 \mathrm{st}$ & - & DHF (59) & 200 & Vietnamese & Lan et. al., 2008 \\
\hline$A^{*} 33$ & - & - & DHF/DSS (309) & 251 & Vietnamese & $\begin{array}{l}\text { Fernández et. al., } \\
2004\end{array}$ \\
\hline$B^{*} 18$ & - & - & DHF/DSS (51) & 95 & $\begin{array}{l}\text { Malay, } \\
\text { (Chinese, } \\
\text { Indian }\end{array}$ & Appanna et. al., 2010 \\
\hline$B^{*} 13$ & 2nd & - & DSS (41) & 138 & Thai & Chiewsilp et. al., 1981 \\
\hline$D R B 1 * 09: 01$ & - & - & DSS (170) & 200 & Vietnamese & Lan et. al., 2008 \\
\hline$D R B 1 * 09: 01$ & - & - & DSS (96) & 200 & Vietnamese & Lan et. al., 2008 \\
\hline$B * 35$ & - & - & DF, DHF/DSS (39) & 34 & Mexican & $\begin{array}{l}\text { Falcón-Lezama et. al., } \\
2009\end{array}$ \\
\hline$D R B 1 * 04$ & $2 n d$ & DV -2 & DF, DHF/DSS (77) & 189 & Cuban & Sierra et. al., 2007 \\
\hline$D R B 1{ }^{*} 07$ & - & DV-2 & DF, DHF/DSS (120) & 189 & Cuban & Sierra et. al., 2007 \\
\hline
\end{tabular}

Table 1. Cases vs. healthy controls Adaptated to [78].

\subsubsection{HLA and hepatitis C}

Hepatitis C virus (HCV) is one of the major causes of chronic liver inflammation worldwide $[79,80]$. HCV was first identified in 1989 [81] and has since then been the subject of intense 
research and clinical investigation due to the role this virus plays in causing liver disease and the ability of HCV to persist despite cellular immune defense.

The majority of the individuals infected by HCV are asymptomatic and only a small number will clear the virus whereas most individuals, approximately $50-85 \%$, end up with persistent chronic viremia. Chronic disease can be evidenced by histopathological changes, which begin with an inflammation of the liver, often associated with fibrosis and which may progress towards cirrhosis, and in some cases, towards hepatocellular carcinoma [82,83]. An estimated $20 \%$ of chronic patients develop cirrhosis, especially 20 years after infection, and of these, 0 to $3 \%$ develop hepatocellular carcinoma $[84,85]$.

The exact mechanisms responsible for liver damage during chronic hepatitis $C$ have not yet been defined. The factors that influence the disease progression include viral genotype, age, gender, duration of the infection, concurrent infections and alcohol abuse; these factors taken individually, however, do not explain the reason that many patients spontaneously recover and escape from persistent infection whereas others progress towards endstage liver disease [86-89].

In this context, these clinical features appear to be the result of the host's immune response, a complex interaction between the innate and adaptive immune response, involved in the control of viral replication. HLA class I and II play an important role in the immune response against viral infections because they are key proteins to antigen presentation by antigen presenting cells to T lymphocytes. Several studies have analyzed HLA class I and class II in patients with hepatitis $C$ in different populations and there is strong evidence that some, mainly HLA class II, alleles are involved in the control of viral infection by HCV. Table 1 summarizes the various HLA class II specificities that have been associated with HCV infection [90-123].

The most consistent data seems to be related to $H L A-D R B 1^{*} 11$ associated with the asymptomatic disease in individuals hosting HCV in Italy (DRB1*11:04 allele) [95], and has been associated with normal levels of alanine aminotransferase (ALT) in patients infected in France [105]. In another study in France, $H L A-D R B 1^{*} 11$ has been more frequently detected in patients without cirrhosis when compared to cirrhotic patients [103]. In Europe, HLA-DRB1*11 has been observed to be less frequent in those individuals who had received transplants for HCVinduced end-stage liver disease compared to blood donors. In fact, $H L A-D R B 1^{*} 11$ seems to be a favorable prognosis factor not only in facilitating spontaneous HCV clearance $[96,98,104,115,124,125]$, but also in increasing resistance against the development of more advanced stages of the chronic HCV infection [121].

Another allele group that has been correlated to self-limiting $\mathrm{HCV}$ is $D Q B 1^{*} 03$ $[101,104,114,124]$. HLA-DQB1*03 is found in linkage disequilibrium (LD) with HLA-DRB1*11 and, alone or in conjunction with $D R B 1^{*} 11$, has been strongly associated with spontaneous viral clearance $[96,100,115,122]$ and with the avoidance of further liver damage in chronically infected hepatitis $C$ virus patients. In a meta-analysis, individuals with $H L A-D R B 1^{*} 11: 01$ and $D Q B 1^{*} 03: 01$ had a reduced risk of acquiring chronic HCV infection in $102 \%$ and $136 \%$, respectively [126]. HLA-DQB1*03 once again seems to influence treatment response, $H L A$ - 
$D Q B 1^{*} 03: 01$ has been associated with sustained viral response (SVR) treated with pegylated interferon-alpha and ribavirin [120]. In another study carried out with patients from Pakistan, an association between $D Q B 1^{*} 03$ and improved antiviral defense in patients treated with inferferon-alpha plus ribavirin was detected [100].

Although some studies have been conducted to evaluate the influence of HLA class I in the course of hepatitis $C$ disease and on the treatment response, the data is not yet consistent. The HLA-B35 antigen has been found more frequently in HCV carriers when compared to healthy individuals [111]. HLA-B*18 has been observed more frequently in patients with advanced stages of fibrosis (F2-F4) [127]. In a study carried out in Spain, this specificity was also more frequently found in patients with hepatocellular carcinoma, suggesting a possible involvement in progression towards more severe forms of the disease and a more unfavorable prognosis [128]. African-American patients with $H L A-A^{*} 23$ showed a higher susceptibility to develop chronic HCV infection [101].

Some HLA class I alleles have been described in treated patients: $H L A-C^{*} 07$ has been associated with SVR in patients on interferon-alpha therapy in Croatia [129]. The HLA-B55, B62, Cw3 and $\mathrm{Cw} 4$ antigens have been associated with improved response to interferon-alpha treatment in Japanese's patients [130]. In Taiwan, the HLA- $A^{*} 11, B^{*} 51, C^{*} 15$ and DRB1*15 allele groups were related to a sustained response to interferon-alpha treatment, whereas $A^{*} 24$ was linked to non-response to treatment [108]. In addition, $H L A-A^{*} 24$ and $B^{*} 40$ as well as haplotypes $B^{*} 40$ $D R B 1^{*} 03, B^{*} 46-D R B 1^{*} 09, C^{*} 01-D Q B 1^{*} 03$ and $C^{*} 01-D R B 1^{*} 09$ were associated with SVR in Taiwan [131]. Furthermore, in Caucasian Americans, $H L A-A^{*} 02$ was associated with SVR [132].

This lack of consensus in the literature may be result of the variations in the methodology of each study, such as different criteria or treatment response diagnoses, sample size, ethnic differences, mixing viral genotypes during analysis, and differences in treatment.

\begin{tabular}{llll}
\hline Associated HLA class II specificity & $\begin{array}{l}\text { Population/ } \\
\text { Country }\end{array}$ & Outcome & Reference \\
\hline$D R B 1 * 04: 05$ and $D Q B 1 * 04: 01$ & Japan & Viral persistence & Aikawa et al. (1996) \\
$D R B 1 * 03: 01$ & Germany & Viral persistence & Hohler et al. (1997) \\
$D R B 1 * 11$ and $D Q B 1 * 03$ & France & Viral clearance & Alric et al. (1997) \\
$D R B 1 * 04: 05$ and $D Q B 1 * 04: 01$ & Japan & Viral persistence & Kuzushita et al. (1998) \\
$D R B 1 * 07$ & Caucasians/France & Nonresponders to & Alric et al. (1999) \\
& IFN-a therapy & \\
$D Q B 1 * 06$ & Caucasians/France & Sustained virological & Alric et al. (1999) \\
$D R B 1 * 10: 01$ and $D R B 1 * 11: 01$ & Italy & Viral persistence & Asti et al. (1999) \\
$D R B 1 * 11: 04$ and $D R B 3 * 03$ & Italy & Protection & Asti et al. (1999) \\
$D Q B 1 * 05: 02$ & Italy & Viral persistence & Mangia et al. (1999)
\end{tabular}




\begin{tabular}{|c|c|c|c|}
\hline Associated HLA class II specificity & $\begin{array}{l}\text { Population/ } \\
\text { Country }\end{array}$ & Outcome & Reference \\
\hline$D R B 1 * 11: 04$ and $D Q B 1 * 03: 01$ & Italy & Viral & Mangia et al. (1999) \\
\hline$D R B 1^{*} 07: 01$, and $D R B 4^{*} 01: 01$ & European (UK) & Viral persistence & Thursz et al. (1999) \\
\hline$D R B 1 * 01$ & Ireland & $\begin{array}{l}\text { Spontaneous } \\
\text { clearance }\end{array}$ & Fanning et al. (2000) \\
\hline$D R B 1 * 03: 01$ and $D Q B 1 * 02: 01$ & Thailand & Viral persistence & Vejbaesya et al. (2000) \\
\hline$D R B 1 * 11$ and $D Q B 1 * 03$ & Caucasians/UK & Viral clearance & Harcourt et al. (2001) \\
\hline$D Q B 1 * 03: 01$ & Black/USA & Viral clearance & Thio et al. (2001) \\
\hline$D R B 1 * 01: 01$ and $D Q B 1 * 05: 01$ & Caucasians/USA & Viral clearance & Thio et al. (2001) \\
\hline$D R B 1 * 03: 01$ and $D Q B 1 * 02: 01$ & Caucasians/USA & Viral persistence & Thio et al. (2001) \\
\hline$D R B 1 * 13$ & Poland & Viral persistence & Kryczka et al. (2001) \\
\hline$D Q B 1 * 02: 01$ & France & Viral persistence & Hue et al. (2002) \\
\hline$D R B 1 * 11$ & Turkey & Protection & $\begin{array}{l}\text { Yenigun \& Durupinar } \\
\text { (2002) }\end{array}$ \\
\hline$D R B 1 * 11$ & France & $\begin{array}{l}\text { less severe liver } \\
\text { disease }\end{array}$ & Renou et al. (2002) \\
\hline$D R 14$ and $D R 17$ & Italy & Viral persistence & Scotto et al. (2003) \\
\hline$D Q B 1 * 05: 03$ & Japan & Viral persistence & Yoshizawa et al. (2003) \\
\hline$D R B 1 * 15$ & Taiwan & $\begin{array}{l}\text { Sustained virological } \\
\text { response }\end{array}$ & Yu et al. (2003) \\
\hline$D Q B 1 * 02: 01$ & Ireland & Viral persistence & McKiernan et al. (2004) \\
\hline$D R B 1 * 07$ & China & $\begin{array}{l}\text { Sustained virological } \\
\text { response }\end{array}$ & Jiao \& Wang (2005) \\
\hline$D R B 1 * 08: 03, D Q B 1 * 06: 01$ and $D Q B 1 * 06: 04$ & Korea & Viral persistence & Yoon et al. (2005) \\
\hline$D R B * 40: 01$ & Taiwan & High viral load & Wang et al. (2005) \\
\hline$D R B 1 * 15$ & Tunisia & Viral persistence & Ksiaa et al. (2007) \\
\hline$D R B 1 * 08$ & Tunisia & $\begin{array}{l}\text { Spontaneous } \\
\text { clearance }\end{array}$ & Ksiaa et al. (2007) \\
\hline$D R B 1 * 03$ & Brazil & Viral clearance & $\begin{array}{l}\text { Cursino-Santos et al. } \\
\text { (2007) }\end{array}$ \\
\hline$D R B 1 * 11, D Q B 1 * 03$ and $D R B 3 * 02$ & USA & Viral clearance & Harris et al. (2008) \\
\hline$D R B 1 * 04$ and $D Q B 1 * 02$ & Egypt & Viral persistence & El-Chennawi et al. (2008) \\
\hline$D Q B 1 * 06$ & Egypt & Protection & El-Chennawi et al. (2008) \\
\hline$D R B 1 * 07$ & Brazil & Viral persistence & Corghi et al. (2008) \\
\hline$D R B 1{ }^{*} 08$ and $D Q B 1 * 04$ & Brazil & Protection & De Almeida et al. (2011) \\
\hline
\end{tabular}




\begin{tabular}{|c|c|c|c|}
\hline Associated HLA class II specificity & $\begin{array}{l}\text { Population/ } \\
\text { Country }\end{array}$ & Outcome & Reference \\
\hline$D R B 1 * 11$ & Brazil & Viral clearance & De Almeida et al. (2011) \\
\hline$D R B 1 * 11$ and $D Q B 1 * 03$ & Brazil & Protection & Cangussu et al. (2011) \\
\hline$D Q B 1 * 03: 01$ & Spain & $\begin{array}{l}\text { Sustained virological } \\
\text { response }\end{array}$ & Rueda et al. (2011) \\
\hline$D R B 1 * 11$ & Brazil & Protection & Marangon et al. (2012) \\
\hline$D R B 1 * 11-D Q A 1 * 05-D Q B 1 * 03$ & Brazil & Protection & Marangon et al. (2012) \\
\hline$D R B 1 * 11$ & Brazil & $\begin{array}{l}\text { Sustained virological } \\
\text { response }\end{array}$ & Marangon et al. (2012) \\
\hline$D R B 1 * 04$ & Pakistan & Protection to HCV & Ali et al. (2013) \\
\hline$D R B 1 * 11$ and $D Q B 1 * 03$ & Pakistan & Viral clearance & Ali et al. (2013) \\
\hline$D R B 1 * 07$ and $D Q B 1 * 02$ & Pakistan & Viral persistence & Ali et al. (2013) \\
\hline$D Q B 1 * 02, D Q B 1 * 06, D R B 1 * 13$ and $D R B 1 * 15$ & Egypt & $\begin{array}{l}\text { Sustained virological } \\
\text { response }\end{array}$ & Shaker et al. (2013) \\
\hline
\end{tabular}

Table 2. HLA class II specificities associated with hepatitis C infection

\subsubsection{HLA and hepatitis $B$}

Similar to $\mathrm{HCV}$, Hepatitis B virus (HBV) is a hepatotrophic virus considered a serious public health problem. HBV infection is endemic in many parts of the world and more than 2 billion people are estimated to be infected with HBV [133-134].

The clinical features of the disease can vary from virus clearance to fulminating hepatitis. Some HBV carriers have an unapparent self-limiting hepatitis and others develop chronic hepatitis, which may lead to cirrhosis and in some cases to hepatocellular carcinoma [133-134].

Persistent HBV infection or HBV clearance is influenced by many factors such as level of viral replication, age at infection, gender, chronic alcohol abuse, co-infection with other hepatitis viruses, and genetic makeup, with most studies having identified susceptibility loci at HLA class II [133-134].

A meta-analysis demonstrated that $H L A-D R^{*} 03$ and $H L A-D R^{*} 07$ were associated with an increased risk of persistent $\mathrm{HBV}$ infection in 18 individual case-control studies including $9 \mathrm{Han}$ Chinese cohorts, 3 Korean cohorts, 2 Iranian cohorts, and 1 cohort each of Caucasian, Gambian, Taiwanese, Thai, and Turkish subjects [135].

In Chinese Han populations, $H L A-D R^{*} 01$ was associated with clearance of HBV infection, whereas in other ethnic groups there was no association between $H L A-D R^{*} 01$ and $\mathrm{HBV}$ infection. 
The haplotypes HLA-DQA1*01:02-DQB1*03:03 and $H L A D Q A 1^{*} 03: 01-D Q B 1{ }^{*} 06: 01$ were associated to persistent HBV infection, whereas $H L A-D Q A 1^{*} 01: 02-D Q B 1^{*} 06: 04$ and $H L A$ $D Q A 1^{*} 01: 01-D Q B 1^{*} 05: 01$ were protective to HBV infection [135].

A genome-wide association study identified a significant association of chronic hepatitis B in Asians with 11 SNPs in a region including HLA-DPA1 and HLA-DPB1 and subsequent analyses revealed risk haplotypes (HLA-DPA1*02:02-DPB1*05:01 and HLA-DPA1*02:02$\left.D P B 1^{*} 03: 01\right)$ and protective haplotypes (HLADPA1* 01:03-DPB1*04:02 and HLA-DPA1*01:03$\left.D P B 1^{*} 04: 01\right)$ for HBV infection [136].

HLA haplotype analysis indicated that $H L A-D Q A 1^{*} 01: 02-D Q B 1^{*} 03: 03$ and $H L A D Q A 1 * 03: 01-$ $D Q B 1^{*} 06: 01$ were risk types for persistent HBV infection, whereas HLA-DQA1*01:02$D Q B 1^{*} 06: 04$ and $H L A-D Q A 1^{*} 01: 01-D Q B 1^{*} 05: 01$ were protective types for HBV infection [137].

\subsubsection{HLA and HIV}

Human immunodeficiency virus (HIV) infection has indeed spread worldwide with over 30 million people living with HIV/AIDS. HIV infection represents a major challenge for physicians and scientists and is typically associated with an acute viral syndrome, with an asymptomatic period until the development of acquire immunodeficiency syndrome (AIDS). When left untreated the infection causes a decline in the CD4+ T cell number to less than 200 cells/ $\mathrm{mm}^{3}$, resulting in immunodeficiency, opportunistic infections, and death [138].

A great number of disease-protective and disease-susceptible HLA alleles have been well characterized in HIV infection and the strongest associations seems to be related to HLA class I alleles (mainly HLA-A and B alleles) with differential rates of HIV disease outcome. Herein, we intend to review and discuss the HLA alleles related to HIV infection.

The virologic and immunologic outcomes in patients with HIV infection can be highly variable, with only a small number of individuals capable of controlling HIV replication without therapy [138]. Despite the mechanism involved in control and progress of HIV infection not yet being fully understood, the implication of some host immunogenetic factors, as the HLA molecules, in the course of disease has been well established.

Earlier studies revealed a relationship between $H L A-B^{*} 27$ and $H L A-B^{*} 57$ and the slow progression to AIDS [139]. Since then, a great number of studies have investigated the influence of HLA class I and class II alleles in both acute and chronic HIV infection and the strongest associations seem to be related to HLA class I alleles.

Regarding the association of HLA class I alleles and protection against HIV infection, the HLA$B^{*} 44$ and $B^{*} 57$ have been described as favorable factors in both the acute and chronic phases of sub-Saharan Africans seroconverters [140]. In China, HLA- $A^{*} 03$ has been described as a protective factor against HIV-1 infection and disease progression [141].

In another study, $H L A-A^{*} 32, A^{*} 74, B^{*} 14, B^{*} 45, B^{*} 53, B^{*} 57$ have been associated with disease control in African Americans infected by HIV-1 subtype B [142].

A large multiethnic cohort with HIV-1 controllers and progressors found diverse alleles associated with virologic and immunologic control: $H L A B^{*} 57: 01, B^{*} 27: 05, B^{*} 14 / C^{*} 08: 02, B^{*} 52$, 
and $A^{*} 25$ [143]. Furthermore, $H L A-B^{*} 13: 02$ [144,145] and $B^{*} 58: 01$ [146-148], have also been described as favorable prognostic factors.

Although all these alleles seem to be implicated in HIV infection the most consistent data are related to three HLA-B specificities: HLA-B*57 (HLA-B*57:01 in European population, *57:02 and *57:03 alleles mainly in African population) [140,143,147-152], HLA $B^{*} 27$ (HLA-B*27:05) $[139,143,145,150]$ and also $H L A-B^{*} 81$ (HLA-B*81:01) $[140,143,146,148]$. These variants are strongly associated with viral load control and slow disease progression in different populations. In fact, the HLA-B molecules have impact on HIV infection as the majority of detectable HIV-specific CD8+T-cell responses described seems to be restricted by HLA-B alleles.

Regarding HIV susceptibility and rapid disease progression, $H L A-B^{*} 35$ ( $B^{*} 35: 01, B^{*} 35: 02$ and 35:03) seems to have the greatest impact on the disease: patients with these alleles seem to have less effective control of viral replication and progress towards AIDS more rapidly [143, 153].

Other unfavorable alleles have been described: $B^{*} 18 /{ }^{*} 18: 01[148,151], B^{*} 45 /{ }^{*} 45: 01[140,148]$, $B^{*} 51: 01$ [148], $B^{*} 53: 01[143,153], B^{*} 58: 02$ [140,146,148], $A^{*} 36: 01[140,148]$, and $B^{*} 07: 02$ [143], however with no actual consistency.

In addition, some HLA-C alleles have been described in association with HIV. HLA-C*08 and $C^{*} 18$ have been associated with viral load [142]. In 2010 and 2011 respectively, HIV escape mutants within cytolitic T lymphocytes (CTL) epitopes restricted of to two different HLA-C alleles were reported: $C^{*} 03$ [154] and $H L A-C^{*} 12: 02$ [155]. In HLA-C associations, some HLA$\mathrm{C}$ alleles tend to be in linkage disequilibrium (LD) with HLA-B alleles and the results could be due to the presence of these HLA-B alleles, such as $B^{*} 81: 01-C^{*} 04: 01$. To elucidate the genetic factors predisposing to AIDS progression, the first genomewide association study (GWAS) identified several new associations, all of them involving HLA genes: MICB, TNF, RDBP, BAT1-5, PSORS1C1, and HLA-C: This study underscores the potential for some HLA genes to control disease progression soon after infection [151].

\subsubsection{HLA and papillomavirus infection}

Infection by human papillomavirus (HPV) is a common sexually transmitted infectious disease and most sexually active women have been infected during their lifetime. HPV infections frequently occur in healthy individuals and the high carcinogenic risk (HR) HPV types are a major causal factor for cervical cancer (CC). Persistent infection with one among approximately 15 genotypes of carcinogenic HPV causes almost all cases of cervical cancer; type 16 and HPV-18 account for more than $70 \%$ of the cervical cancers detected worldwide $[156,157]$.

A number of genetic risk factors have been identified, but their effects are generally weak. The most prominent among the known risk factors is the HLA complex, which plays a critical role in susceptibility to CC [3]. Since the first reported association of HLA-DQ3 with CC, a large number of studies of HLA association with cervical cancer have been published with variable results depending on the ethnic group $[157,158]$.

A study with CC described that $D R B 1^{*} 04: 07-D Q B 1^{*} 03: 02$ and DRB1*15:01-DQB1*06:02 were clearly associated with susceptibility to HPV-16 positive invasive CC, high squamous intrae- 
pithelial lesion (HSIL), and carcinoma in situ [159]. Studies with Honduran women showed HLA-DQA1*03:01 in linkage disequilibrium with all HLA-DR4 subtypes in Mestizos, as an increased risk of developing high squamous intraepithelial lesion and CC [160]

Some DR-DQ haplotypes containing $D Q B 1^{*} 03: 01$ have been positively associated with CC susceptibility: $D R B 1^{*} 11: 01-D Q B 1^{*} 03: 01$ in Senegalese and US Caucasian Europeans, and $D R B 1^{*} 04: 01-D Q B 1^{*} 03: 01$ in US Caucasian Europeans and British females. DRB1*11:02$D Q B 1^{*} 03: 01$ was also increased in Hispanics with carcinoma in situ or HSIL.

Protection has been mainly linked with the $H L A-D R B 1^{*} 13$ group: $D R B 1^{*} 13: 01$ in patients from Costa Rica, and DRB1*13:01-DQB1*06:03-DQA1*01:03 in Swedish, French and Dutch women with CC. A protective effect against CC progression was also claimed to be correlated with $D Q B 1^{*} 05, D Q A 1^{*} 01: 01 / 04, D R B 1^{*} 01: 01$ and DRB1*13:02 in Brazilians. In Caucasians, HLA$D R B 1^{*} 13$ and HPV-16/18-negative status, were independently associated with an increased probability of regression of low squamous intraepithelial lesion (LSIL), also suggesting a protective effect against CC progression [161-163].

Continuing trials pursue an explanation for the relationship between HLA and HPV infection. Silva (2013) showed that $H L A-D Q B 1^{*} 05: 01$ allele might be associated with susceptibility of HPV reinfection in Mexican women, allele frequency of $H L A-D R B 1^{*} 14$ was particularly reduced in patients with cancer when compared with the HPV-persistent group $(\mathrm{p}=0.04)$, suggesting that this allele is a possible protective factor for the development of cervical cancer.

A study analyzed the associations between HLA-G polymorphisms and HPV infection and squamous intraepithelial lesions (SIL) in Inuit women from Nunavik, northern Quebec. The group demonstrated that $H L A-G^{*} 01: 01: 01$ was associated with an increased risk of period prevalent alpha groups 1 and 3 [164]. The $H L A-G^{*}$ 01:04:01 genotype was associated with a decreased risk of alpha group 3 infection period prevalence. No HLA-G alleles were significantly associated with HPV persistence. $H L A-G^{*} 01: 01: 02, G^{*}$ 01:04:01 and $G^{*} 01: 06$ were associated with HSIL, however the association did not reach statistical significance. In this trial, HPV genotypes were classified according to tissue-tropism groupings of alpha-papillomavirus species: alpha group 1 including low risk (LR) cervical species, group 2 including high risk (HR) cervical species, and group 3 including LR vaginal species.

One Korean study related the relationship between HLA and recurrent respiratory papillomatosis (RRP) and showed that the gene frequencies of $H L A-D R B 1^{*} 11: 01$ and $D Q B 1^{*} 03: 01$ and the haplotype frequency of $D R B 1^{*} 11: 01-D Q B 1^{*} 03: 01$ were higher in RRP patients than in controls. $D R B 1^{*} 11: 01$ and $D R B 1^{*} 11: 01-D Q B 1^{*} 03: 01$ haplotype were strongly associated with disease susceptibility to severe RRP in Koreans [165]. In Brazil, the HLA-A*02-HLA-B*51 haplotype presented a reduced frequency in HPV patients compared to controls; and was associated with resistance against the disease [156].

In China population, HLA-DRB alleles were associated with cervical cancer and HPV infections [166]. For the assessment of these genotypes, 69 cervical cancer patients and 201 controls were examined. $H L A-D R B 1^{*} 13$ and $D R B 1^{*} 03(17)$ were associated with an increased risk of cervical cancer, and $D R B 1^{*} 09: 012$ and $D R B 1^{*} 12: 01$ were associated with a decreased risk. The 
risk associations of HPV infection were increased in women carrying HLA-DRB1*09:012 and DRB3(52)*01:01 alleles.

Among cervical cancer patients, the association risks differed between HPV positive and negative cases for several alleles; an increased risk of cervical cancer was observed in patients with $D R B 3(52)^{*} 02 / 03$ and $D R B 1^{*} 3(17)$ and a decreased risk was observed with $D R B 1^{*} 09: 012$ and $D R B 5(51) * 01 / 02[166]$.

\subsection{Parasitic diseases}

\subsubsection{HLA and Chagas disease}

Many genetic linkage and association studies have attempted to identify genetic variations that are involved in immunopathogenesis of Chagas disease. However, the causal genetic variants underlying susceptibility remain unknown due to parasite and host complexity [167]. Susceptibility or resistance to Chagas disease involves multiple genetic variants functioning jointly, each with small or moderate effects. To identify possible host genetic factors that may influence the clinical course of Chagas disease, the role of classic and non-classic MHC genes will be addressed.

Chagas disease is an infection caused by the protozoan Trypanosoma cruzi, described in 1907 by Carlos Chagas. The disease is endemic and is characterized by acute and chronic phases, which develop into the indeterminate, cardiac and/or gastrointestinal forms $[168,169]$. Ten million people are estimated to be infected with T. cruzi worldwide, mostly in Latin America (WHO, 2012) with a total estimated incidence of 800,000 new cases per year [170].

The mechanisms of the transmission of Chagas infection include transmission through insect vectors mainly, but blood transfusion, contaminated food, congenital and secondary transmissions mechanism may occur [171].The phases of infection include the early or acute phase, characterized by high parasitaemia or trypomastigote circulating forms in the blood for two to four months [170]. Mortality, during this period, ranges from $5 \%$ to $10 \%$ due to episodes of myocarditis and meningocefalite $[172,173]$.

The clinical signs are a local inflammatory reaction with formation of strong swelling at the site of entry of the parasites (chagoma or Romaña sign), fever, splenomegaly and cardiac arrhythmia [174]. During the acute phase, the majority of the infected individuals develop a humoral and cellular immune response responsible for the decrease of parasites in the blood.

Following this phase, patients progress to the chronic asymptomatic stage which affects most individuals (50 to $60 \%$ ): this condition characterizes the indeterminate clinical form (IND) of the disease, and may remain in effect for long periods of time [175]. Approximately $20 \%$ to $30 \%$ of the individuals develop cardiomyopathy, which reflects a progressively damaged myocardium due to extensive chronic inflammation and fibrosis and, in terminal phases, usually presents as dilated cardiomyopathy. Chronic Chagas cardiomyopathy (CCC) is the most relevant clinical manifestation leading to death from heart failure in endemic countries. Eight to $10 \%$ have the digestive form (DF), characterized by dilation of the oesophagus or colon 
(megaoesophagus and megacolon). Some patients have associated cardiac and digestive manifestations, known as the mixed or cardiodigestive form [176-178].

There is a consensus that during T. cruzi infection the host immune system induces complex processes to ensure the control of parasite growth. The immune response is crucial for protection against the disease; however, immunological imbalances can lead to heart and digestive tract lesions in chagasic patients. Several studies have evaluated the innate, cellular and humoral immune responses in chagasic patients in an attempt to correlate immunological findings with clinical forms of Chagas disease. However, in all clinical forms of Chagas disease the involvement of cell-mediated immunity is undoubtedly of major importance [179-189].

The spectrum of expression of Chagas disease brings strong evidence of the influence of the genetic factors on the clinical course of the disease, and the polymorphic genes involved in the innate and specific immune response is being widely studied such as the molecules and genes in the region of the HLA.

The polymorphic HLA class I (A, B and C) and II (DR, DQ and DP) molecules determine the efficiency of presentation of the T. cruzi epitopes to $\mathrm{CD} 8^{+}$and $\mathrm{CD} 4^{+} \mathrm{T}$-cells, respectively. The type of the presentation could affect the clinical course of diseases because patients may respond differently to the same antigen, depending on their HLA repertory [190]. Several HLA alleles and haplotypes have been reported to be associated with Chagas disease.

Regarding the association of HLA and Chagas disease, HLA-Dw22 was firstly associated to the susceptibility of developing the disease in Venezuelans [191]. A subsequent study compared class II allele frequencies between patients and controls and identified a decreased frequency of $D R B 1^{*} 14$ and $D Q B 1^{*} 03: 03$ in patients, suggesting protective effects unrelated to chronic infection in this population [192]. A study in southeastern Brazil showed that HLA$A^{*} 30$ confers susceptibility to Chagas disease, whereas $H L A-D Q B 1^{*} 06$ confers protection, regardless of the clinical form of the disease [193] and, in a South Brazilians population, HLADR2 antigens were related to susceptibility to chronic Chagas disease [194]. HLA-DR4 and HLA-B39 were associated with the infection by the T. cruzi in the Mexican population [195] and HLA-DRB1*04:09 and DRB1*15:03 in Argentineans [196,197]. In the latter study, $D R B 1^{*} 11: 03$ allele was associated with disease resistance [197]. The haplotype HLA-DRB1*14$D Q B 1^{*} 03: 01$ was involved in resistance to T. cruzi infection in the rural mestizo population of Southern Peru [198] and the HLA-DRB1*01- $B^{*} 14-M I C A^{*} 011$ haplotype was associated with resistance against chronic Chagas disease in Bolivian individuals [199].

As to the association of HLA and the clinical form of CCC, the first publication related HLA$\mathrm{B} 40$ antigen, in the presence of $\mathrm{Cw} 3$, with a resistance to cardiac manifestations in Chilean patients [200], which was later confirmed [201]. However, $H L A-C^{*} 03$ was associated with susceptibility to cardiomiopathy in the Venezuelan T. cruzi serologically positive individuals [202]. An increase of HLA-A31, B39, DR8, HLA-DR16 and DRB1*15:03 and HLA-DPB1*04:01 alleles and a decrease of HLA-A68, DR4, DR5, DQ1, DQ3 and DRB1*15:01 were observed in several Latin American mestizos from different countries with CCC [192,195,203,204]. $D P B 1^{*} 04: 01-H L A-D P B 1^{*} 23: 01$ and $D P B 1^{*} 04: 01-D P B 1 * 39: 01$ haplotypes were susceptibility factors in this clinical form [204]. 
The studies conducted with the mixed or cardiodigestive form revealed that $D R B 1^{*} 01$, $D R B 1^{*} 08$ and $D Q B 1^{*} 05: 01$ was more frequent in patients conferring susceptibility to the disease [192], as occurs with the HLA-DPB1*04:01 allele in homozygous or in combination with HLA$D P B 1^{*} 23: 01$ or $D P B 1^{*} 39: 01$ [204]. Contrarily, a decreased frequency of $D R B 1^{*} 15: 01$ was found in patients with arrhythmia and congestive heart failure, conferring resistance against these disorders [192,204]. Recently, resistance conferred by HLA-DRB1*01 and HLA-B*14:02 was associated with the patients suffering from megacolon, as well as in those with ECG alterations and/or megacolon when they were compared with a group of patients with indeterminate symptoms [199].

Another study showed that contrarily, the polymorphism of HLA-DR and -DQ molecules did not influence the susceptibility to different clinical forms of Chagas' disease or the progression to severe Chagas' cardiomyopathy [205].

The polymorphism of MICA may be involved in the susceptibility to various diseases; however this association has been suggested to be secondary, due to the strong linkage disequilibrium with HLA-B alleles. MICA*011, which was closely linked to $H L A-B^{*} 14$ and $D R B 1^{*} 01$, might stimulate $\mathrm{T} \gamma \delta$ cells in the gut mucosa, a phenomenon that could be related to megacolon [206]. In Chagas disease the same $H L A-D R B 1^{*} 01-B^{*} 14-M I C A^{*} 011$ haplotype was associated with resistance against the chronic form [199]. MICA-A5 and HLA-B35 synergistically enhanced susceptibility to CCC [207].

These different results between the HLA allele and haplotypes and Chagas disease could be the result of the variability of HLA allele's distribution in different ethnic groups, the selection of the patients and the clinical form, and the biological variability of the parasite, among other factors. Nevertheless, genetic factors related to the HLA system reflect an important role in susceptibility or protection to Chagas disease and its clinical forms.

\subsubsection{HLA and malaria}

Malaria is an infectious disease caused by intracellular protozoan of the genus Plasmodium. Genes located in the HLA complex appear to protect populations in endemic areas against the severe forms caused by Plasmodium falciparum and Plasmodium vivax.

The antibody response generated during malaria infections is of particular interest, since the production of specific IgG antibodies is required for acquisition of clinical immunity. However, variations in antibody responses could result from genetic polymorphism s of the HLA class II genes. Given the increasing focus on the development of subunit vaccines, studies of the influence of class II alleles on the immune response in ethnically diverse populations is important, prior to the implementation of vaccine trials. Junior et al.(2012) showed that HLA$D R B 1^{*} 04$ alleles were associated with a high frequency of antibody responses to five out of nine recombinant proteins tested in Rondonia State, Brazil [208].

The Fulani of West Africa have been shown to be less susceptible to malaria and to mount a stronger immune response to malaria than sympatric ethnic groups. HLA-DRB1*04 and $D Q B 1^{*} 02$ have been shown to be implicated in the development of several autoimmune 
diseases, to be present at high frequency in the Fulani, suggesting their potential involvement in the enhanced immune reactivity observed in this population [209].

Trials have been performed seeking to determine the associations between HLA-A, B, and DRB1 group of alleles and severe malaria in northern Ghana. HLA-DRB1*04 was analyzed in 4,032 subjects from a severe malaria case-control study, 790 severe malaria cases, 1,611 mild malaria controls, and 1631 asymptomatic controls. The presence of $H L A-D R B 1^{*} 04$ was associated with severe malaria. The frequency of $D R B 1^{*} 04$ was similar in the two major ethnic groups in the study population, Kassem (4.4\%) and Nankam (4.7\%), and the OR for the association between $D R B 1^{*} 04$ and severe malaria was similar in both ethnic groups. These findings were consistent with results from Gabon suggesting that $D R B 1^{*} 04$ to be a risk factor for severe malaria [210].

To test for associations between HLA alleles and the severity of malaria in a Thai population, polymorphisms of HLA-B and HLA-DRB1 genes were investigated in 472 adult patients in northwest Thailand with Plasmodium falciparum malaria. In the study, malaria patients were classified into three groups: mild malaria, non-cerebral severe malaria, and cerebral malaria. The results revealed that the allele frequencies of $H L A-B^{*} 46, B^{*} 56$, and $D R B 1^{*} 10: 01$ were statistically different between non-cerebral severe malaria and cerebral malaria, between mild malaria and cerebral malaria $(\mathrm{P}=0.032)$, and between mild malaria and non-cerebral malaria [211].

Individuals from Mumbai, an area of low and seasonal Plasmodium falciparum transmission, were investigated for HLA associations. A cohort of 171 severe $P$. falciparum malaria patients were compared with that of 101 normal gender, age, and ethnically matched control samples. Significant differences were observed between patients with malaria and controls in the following HLA: A3, B27, B49, DRB1*04, and DRB1*08:09, which were increased, whereas A19, A34, B18, B37, and DQB1*02:03 were decreased. HLA B49 and DRB1*08:09 were found to be positively associated with the complicated severe malaria patients. HLA-A19, B5 and B13 were protective in patients with high parasite index $(>2 \%)$. These observations revealed the importance of ethnic background, which has to be taken into consideration when developing an ideal malaria vaccine. Furthermore, when compared to HLA associations of other world populations the study indicated the relative importance of different HLA alleles that may vary in different populations [212].

\section{Concluding remarks}

Many genetic linkage and association studies have attempted to identify HLA variations that are involved in immunopathogenesis of infection diseases. However, in the infection diseases multiple genetic variants functioning jointly, each with small or moderate effects, may protect against diseases, or could contribute to aggression and tissue damage. Different results between the alleles and haplotypes HLA and infection diseases could be caused by: variability of HLA alleles distribution in different ethnic groups; the typing test (serological or molecular techniques); the methods of statistical analyses (chi-square test, logistic or linear regression) 
and interpretation ( $p$ or $p c$ values that apply the Bonferroni correction for multiple comparations); the selection of the patients and the clinical form; the numbers of individuals; linkage disequilibrium that vary among populations; and biological variability of the parasite.

The characterisation of the susceptibility genes and their variants has important implications, not only for a better understanding of disease pathogenesis, but for the control and development of new therapeutic strategies for infectious diseases. Using the basic knowledge acquired in the studies of the influence of genetics upon the immune response against parasite in different populations, one can look for proteins that induce the immunological phenotype needed for protection. At present, vaccination is an effective preventive measurement for these disorders, and researches for peptides with the best-predicted binding affinities for HLA molecules are an alternative. Overall, this type of analysis could potentially define high-risk patient groups, and result in effective therapeutic strategies for infectious disorders.

\section{Author details}

Daniela Maira Cardozo ${ }^{1}$, Amanda Vansan Marangon ${ }^{1}$, Ana Maria Sell², Jeane Eliete Laguila Visentainer ${ }^{2}$ and Carmino Antonio de Souza ${ }^{1}$

1 Immunogenetics Laboratory, Hematology and Hemotherapy Center-University of Campinas/Hemocentro-Unicamp, Instituto Nacional de Ciência e Tecnologia do Sangue, Campinas, São Paulo, Brazil

2 Immunogenetics Laboratory, Department of Healthy Basic Science, Maringá State University, UEM, Maringá, Paraná, Brazil

\section{References}

[1] Jawdat D, Al Saleh S, Sutton P, Al Anazi H, Shubaili A, Uyar FA, et al. HLA-C Polymorphisms in two cohorts of donors of bone marrow transplantation. Saudi J Kidney Dis Transpl. 2012;23:467-70. http://www.sjkdt.org/article.asp?issn=1319-2442; year=2012; volume=23; issue $=3$; spage $=467$; epage $=470$; aulast $=$ Jawdat (accessed $13 \mathrm{Au}$ gust 2012).

[2] Voltarelli JC, Pasquini R, Ortega ETT, Transplante de Células-Tronco Hematopoiéticas. Ed. Atheneu 2010.

[3] Bjorkman PJ, Saper MA, Samraoui B, Bennett WS, Strominger JL, Wiley DC. Structure of the human class I histocompatibility antigen, HLA-A2. J Immunol 2005;174:6-9. http://www.jimmunol.org/content/174/1/6.long (accessed 13 August 2012). 
[4] Steinmetz M, Hood L. Genes of the major histocompatibility complex in mouse and man. Science 1983; 222: 727-33. http://www.sciencemag.org/content/ 222/4625/727.long (accessed 14 August 2012)

[5] Le Bouteiller P. HLA class I chromosomal region, genes, and products: facts and questions. Critical Reviews in Immunology1994;14:89-129. http:// www.ncbi.nlm.nih.gov/pubmed?term=HLA\%20class\%20I\%20chromosomal\%20region $\% 2 \mathrm{C} \% 20$ genes $\% 2 \mathrm{C} \% 20$ and $\% 20$ products $\% 3 \mathrm{~A} \% 2$ (accessed 16 August 2012).

[6] Bjorkman PJ, Saper MA, Samraoui B, Bennett WS, Strominger JL, Wiley DC. The foreign antigen binding site and $\mathrm{T}$ cell recognition regions of class I histocompatibility antigens. Nature 1987;329:512-8. http://www.nature.com/nature/journal/v329/ n6139/abs/329512a0.html (accessed 18 August 2012).

[7] Rammensee HG, Friede T, Stevanovic S. MHC ligands and peptide motifs: first listing. Immunogenetics 1995;41:178-28. http://www.ncbi.nlm.nih.gov/pubmed? term $=$ MHC $\% 20$ ligands $\% 20$ and $\% 20$ peptide $\% 20$ motifs $\% 3 \mathrm{~A} \% 20$ first $\% 20$ listing $\quad$ (accessed 29 August 2012).

[8] Salter RD, Benjamin RJ, Wesley PK, et al. A binding site for the T-cell co-receptor CD8 on the alpha 3 domain of HLA-A2. Nature 1990;345:41-6. http:// www.nature.com/nature/journal/v345/n6270/abs/345041a0.html (accessed 30 August 2012).

[9] Croft M, Dubey C. Accessory molecule and costimulation requirements for CD4 T cell response. Crit Rev Immunol.1997;17:89-118. http:/www.ncbi.nlm.nih.gov/ pubmed?term=Accessory $\% 20$ molecule $\% 20$ and $\% 20$ costimulation $\% 20$ requirements \%20for\%20CD4\%20T\%20cell\%20response (accessed 02 September 2012).

[10] Kaleab BR, Kiessling JD, van Embden JE, Thole DS, Kumararatne P, Pisa A, Wondimu and Ottenhoff THM. Induction of antigen-specific CD41 HLA-DR-restricted cytotoxic $\mathrm{T}$ lymphocytes as well as nonspecific nonrestricted killer cells by the recombinant mycobacterial 65-kDa heat-shock protein. Eur. J. Immunol. 1990;20:369.

[11] Mutis T, Cornelisse YE and Ottenhoff THM. Mycobacteria induce CD41 T cells that are cytotoxic and display Th1-like cytokine secretion profile: heterogeneity in cytotoxic activity and cytokine secretion levels. Eur. J. Immunol. 1993;23:2189.

[12] Hunter SW, Gaylord H, Brennan PJ. Structure and antigenicity of the phosphorylated lipopolysaccharide antigens from the leprosy and tubercle bacilli. J Biol Chem. 1986;26: 12345-51.

[13] Meyers WM. Leprosy. Dermatol Clin. 1992;10:73-96.

[14] World Health Organization, "Global leprosy: update on the 2012 situation," Weekly Epidemiological Record. 2013, 88:365-380.

[15] WHO Expert Committee on leprosy. 17th report. Geneva, World Health Organization; 1998. (Technical Report Series, 874). 
[16] Brandsma JW, Heerkens YF, Lakerveld-Heyl K, Mischner-Van Ravensberg CD. The international classification of impairments, disabilities and handicaps in leprosy-control projects. Lepr Rev. 1992;63:337-44.

[17] Schurr E, Morgan K, Gros P, Skamene E. Genetics of leprosy. Am J Trop Med Hyg. 1991;44:4-11. http://www.ajtmh.org/content/44/4_Part_2/4.long (accessed 23 October 2013).

[18] Spierings E, De Boer T, Zulianello L, Ottenhoff TH. Novel mechanisms in the immunopathogenesis of leprosy nerve damage: the role of Schwann cells, T cells and Mycobacterium leprae. Immunol Cell Biol. 2000;78:349-55. http://www.nature.com/icb/ journal/v78/n4/full/icb200047a.html (accessed 02 October 2013).

[19] Marquet $S$ and Schurr E. Genetics of susceptibility to infections disease: tuberculosis and leprosy as example. Drug Metab Dispos. 2001;29:479-83. http://dmd.aspetjournals.org/content/29/4/479.long (accessed 03 September 2013).

[20] Bale UM, Mehta MM, Contractor NM. HLA antigens in leprosy patients. Tissue Antigens. 1982;20:141-143. http://www.ncbi.nlm.nih.gov/pubmed/?term=Bale+1982+leprosys (accessed 03 October 2013).

[21] Agrewala JN, Ghei SK, Sudhakar KS, Girdhar BK, Sengupta U. HLA antigens and erythema nodosum leprosum (ENL). Tissue Antigens. 1989;33:486-487.

[22] Rani R, Zaheer SA, Mukherjee R. Do human leukocyte antigens have a role to play in differential manifestation of multibacillary leprosy: a study on multibacillary leprosy patients from North India. Tissue Antigens. 1992;40:124-127.

[23] Shankarkumar U, Ghosh K, Badakere S, Mohanty D. Novel HLA class I alleles. Associated with Indian leprosy patients. Journal of Biomedicine and Biotechnology. 2003;3:208-211. http://www.ncbi.nlm.nih.gov/pmc/articles/PMC400212/ (accessed 02 October 2013).

[24] Shankarkumar U. HLA associations in leprosy patients from Mumbai, India. Leprosy Review. 2004;75:79-85. http://www.ncbi.nlm.nih.gov/pmc/articles/PMC400212/ (Accessed 29 September 2013).

[25] Franceschi DSA, Tsuneto LT, Mazini PS et al., Class-I human leukocyte alleles in leprosy patients from southern Brazil. Revista da Sociedade Brasileira de Medicina Tropical. 2011;44:616-620.

[26] Alter A, Huong NT, Singh M et al., Human leukocyte antigen class I region singlenucleotide polymorphisms are associated with leprosy susceptibility in Vietnam and India. The Journal of Infectious Diseases. 2011;203:1274-1281.

[27] Mehra NK, Verduijn W, Taneja V, Drabbels J, Singh SP, Giphart MJ. Analysis of HLA-DR2-associated polymorphisms by oligonucleotide hybridization in an Asian Indian population. Hum Immunol. 1991;32:246-53. 
[28] Visentainer JEL, Tsuneto LT, Serra MF, Peixoto PRF and Petzl-Erler ML. Association of leprosy with HLA-DR2 in a Southern Brazilian population. Brazilian Journal of Medical and Biological Research. 1997;30:51-59.

[29] Singh M, Balamurugan A, Katoch K, Sharma SK and Mehra NK. Immunogenetics of mycobacterial infections in the North Indian population. Tissue Antigens. 2007;69:228-230.

[30] Vanderborght PR, Pacheco AG, Moraes ME et al. HLADRB1*04 and DRB1*10 are associated with resistance and susceptibility, respectively, in Brazilian and Vietnamese leprosy patients. Genes and Immunity. 2007;8:320-324.

[31] da Silva SA, Mazini PS, Reis PG, et al. HLA-DR and HLADQ alleles in patients from the south of Brazil: markers for leprosy susceptibility and resistance. BMC Infectious Diseases. 2009;9:134-140. http://www.ncbi.nlm.nih.gov/pmc/articles/PMC2746224/ (Accessed 30 September 2013).

[32] Zhang F, Liu H, Chen S, et al. Evidence for an association of HLA-DRB1*15 and DRB1*09 with leprosy and the impact of DRB1*09 on disease onset in a Chinese Han population. BMC Medical Genetics. 2009;10:133. http://www.ncbi.nlm.nih.gov/pmc/ articles/PMC2797507/ (Accessed 12 October 2013).

[33] Correa RDG, Aquino DM, Caldas ADJ, et al. Association analysis of human leukocyte antigen class II, (DRB1) alleles with leprosy in individuals from São Luís, state of Maranhão, Brazil. Memórias Instituto Oswaldo Cruz. 2012;107:150-155. http:// www.scielo.br/scielo.php?script=sci_art-

text\&pid=S0074-02762012000900022\&lng=en\&nrm=iso\&tlng=en (accessed 12 October 2013).

[34] Koçak M, Balci M, Pençe B and Kundakç N. Associations between human leukocyte antigens and leprosy in the Turkish population. Clinical and Experimental Dermatology. 2002;27:235-239. http://onlinelibrary.wiley.com/doi/10.1046/j. 1365-2230.2002.01004.x/full (Accessed 23 October 2013).

[35] Borrás SG, Cotorruelo C, Racca L, et al. Association of leprosy withHLA-DRB1 in an Argentinean population. Annals of Clinical Biochemistry. 2008;45:96-98. http:// acb.sagepub.com/content/45/1/96.long (Accessed 12 October 2013).

[36] Agrewala JN and Wilkinson RJ. Influence of HLA-DR on the phenotype of CD4+ T lymphocytes specific for an epitope of the 16-kDa alpha-crystallin antigen of Mycobacterium tuberculosis. European Journal of Immunology. 1999;29:1753-1761. http:// onlinelibrary.wiley.com/doi/10.1002/(SICI)1521-4141(199906)29:06\%3C1753::AID-IMMU1753\%3E3.0.CO;2-B/pdf (Accessed 23 September 2013).

[37] Mutis T, Cornelisse YE, Datema G, van den Elsen PG, Ottenhoff THM and de Vries RRP. Definition of a human suppressor T-cell epitope. Proceedings of the National Academy of Sciences of the United States of America. 1994;91:9456-9460. http:// www.ncbi.nlm.nih.gov/pmc/articles/PMC44831/ (Accessed 12 September 2013). 
[38] Joko S, Numaga J, Kawashima H, Namisato M and Maeda H. Human leukocyte antigens in forms of leprosy among Japanese patients. International Journal of Leprosy and Other Mycobacterial Diseases. 2000;68:49-56. http://www.ncbi.nlm.nih.gov/ pubmed/10834069 (Accessed 10 September 2013).

[39] Motta PMF, Cech N, Fontan C, et al. Role of HLA-DR and HLA-DQ alleles in multibacillary leprosy and paucibacillary leprosy in the province of Chaco (Argentina). Enfermedades Infecciosas y Microbiologia Clinica. 2007;25:627-631. http:// www.ncbi.nlm.nih.gov/pubmed/18053473 (Accessed 02 September 2013).

[40] Hsieh NK, Chu CC, Lee NS, Lee HL and Lin M. Association of HLA- DRB1*0405 with resistance to multibacillary leprosy in Taiwanese. Human Immunology. 2010;71:712-716. http://www.sciencedirect.com/science/article/pii/S0198885910000790 (Accessed 11 October 2013).

[41] Goldfeld AE, Delgado JC, Thim S, Bozon MV, Uglialoro AM, Turbay D, Cohen C, Yunis EJ. Association of an HLA-DQ allele with clinical tuberculosis. JAMA. 1998;279:226-8. http://jama.jamanetwork.com/article.aspx?articleid=187149 (Accessed 30 September 2013).

[42] Zerva L, Cizman B, Mehra NK, Alahari SK, Murali R, Zmijewski CM, Kamoun M, Monos DS. Arginine at positions 13 or 70-71 in pocket 4 of HLA-DRB1 alleles is associated with susceptibility to tuberculoid leprosy. J Exp Med. 1996;183:829-36. http:// www.ncbi.nlm.nih.gov/pmc/articles/PMC2192353/ (Accessed 14 October 2013).

[43] Dye, C, Williams, BG, Espinal, MA, Raviglione, MC. Erasing the world's slow stain: strategies to beat multidrug-resistant tuberculosis. Science. 2002. 295:2042-2046. DOI: 10.1126/science.1063814.

[44] Frigui W, Bottai D, Majlessi L, Monot M, Josselin E, Brodin P, Garnier T, Gicquel B, Martin C, Leclerc C, Cole ST, Brosch R. Control of M. tuberculosis ESAT-6 secretion and specific $T$ cell recognition by PhoP. PLoS Pathog. 2008;8:e33. http:// www.ncbi.nlm.nih.gov/pmc/articles/PMC2242835/ (accessed 10 October 2013).

[45] Urdahl KB, Shafiani S, Ernst JD. Initiation and regulation of T-cell responses in tuberculosis. Mucosal Immunol. 2011; 4(3):288-93. http://www.ncbi.nlm.nih.gov/pmc/articles/PMC3206635/ (accessed 10 September 2013).

[46] Hoal EG. Human genetic susceptibility to tuberculosis and other mycobacterial diseases. IUBMB Life. 2002;53:225-229. http://onlinelibrary.wiley.com/doi/ 10.1080/15216540212644/abstract (accessed 10 September 2013).

[47] Malik S and Schurr E. Genetic susceptibility to tuberculosis. Clinical Chemistry and Laboratory Medicine. 2002;40:863-868. DOI: 10.1515/CCLM.2002.153.

[48] Kettaneh L, Seng KP, Tiev C, Tolédano B, Fabre JC. Human leukocyte antigens and susceptibility to tuberculosis: a meta-analysis of case-control studies. Int J Tuberc 
Lung Dis. 2006;10:717-725. http://www.ncbi.nlm.nih.gov/pubmed/16848331 (accessed 03 September 2013).

[49] Selvaraj P, Reetha AM, Uma H, et al. Influence of HLA-DR and -DQ phenotypes on tuberculin reactive status in pulmonary tuberculosis. Tuber Lung Dis 1996;77:369-73.

[50] P. Selvaraj D, Nisha Rajeswari MS, Jawahar PRN. Influence of HLA-DRB1 alleles on Th1 and Th2 cytokine response to Mycobacterium tuberculosis antigens in pulmonary tuberculosis. Tuberculosis. 2007;87:544-550. http://www.tuberculosisjournal.com/ article/S1472-9792(07)00089-3/abstract (accessed 10 September 2013).

[51] Dubaniewicz A, Lewko B, Moszkowska G, Zamorska B, Stepinski J. Molecular subtypes of the HLA-DR antigens in pulmonary tuberculosis. International Journal of Infectious Diseases. 2000;4:129-133. http://www.ncbi.nlm.nih.gov/pubmed/11179915 (accessed 10 September 2013).

[52] Rojas-Alvarado MDL, Diaz-Mendoza ML, Said-Fernandez S, Caballero-Olın G, Cerda-Flores RM. Association of pulmonary tuberculosis with HLA systemantigens in Northeastern Mexico. Gaceta Medica de Mexico. 2008;144:233-238.

[53] Lombard Z, Dalton D, Venter PA, Williams RC and Bornman L. Association of HLADR, -DQ, and vitamin D receptor alleles and haplotypes with tuberculosis in the Venda of South Africa. Human Immunology. 2006;67:643-654. http://www.sciencedirect.com/science/article/pii/S0198885906001078 (accessed 15 October 2013).

[54] Dubaniewicz A. and Moszkowska G. Analysis of occurrence of DRB and DQ alleles in sarcoidosis and tuberculosis from Northern Poland. Pneumonologia i Alergologia Polska. 2007;75:13-21. http://www.ncbi.nlm.nih.gov/pubmed/17541908 (accessed 03 September 2013).

[55] Wu F, Zhang W, Zhang L, Wu J, Li C, Meng X, Wang X, He P, Zhang J. NRAMP1, VDR, HLA-DRB1, and HLA-DQB1 Gene Polymorphisms in Susceptibility to Tuberculosis among the Chinese Kazakh Population: A Case-Control Study. BioMed Research International. 2013;2013:1-8. http://www.ncbi.nlm.nih.gov/pmc/articles/ PMC3758880/ (accessed 04 September 2013).

[56] Mangold KA, Reynolds SL. A review of dengue fever: resurging tropical disease. Pediatric Emergency Care. 2013;29:665-669. http://www.ncbi.nlm.nih.gov/pubmed/ 23640151 (accessed 17 September 2013).

[57] Ministério da Saúde. "Tabulação de dados. Dengue - Notificações registradas no sistema de informação de agravos de notificação," - SinanNet, 2011. [cited 2011 September 08]. Available from: dtr2004.saude.gov.br/sinanweb/index.php.

[58] Appanna R, Ponnampalavanar S, Chai See LL and Sekaran SD. Susceptible and protective HLA class I alleles against Dengue Fever and Dengue Hemorrhagic Fever patients in a Malaysian population. Plos One. 2010;5:e13029. http:// www.ncbi.nlm.nih.gov/pmc/articles/PMC2946915/ (accessed 14 September 2013). 
[59] Dong T, Moran E, Vinh Chau N, et al. High proinflammatory cytokine secretion and loss of high avidity cross-reactive cytotoxic hemorrhagic fever and virus load in a dengue-2 outbreak. Clinical Immunology. 2007;131:404-409. http:// www.ncbi.nlm.nih.gov/pmc/articles/PMC2092391/ (accessed 14 September 2013).

[60] Ubol S, Masrinoul P, Chaijaruwanich J, et al. Differences in global gene expression in peripheral blood mononuclear cells indicate a significant role of the innate responses in progression of Dengue Fever but not Dengue Hemorrhagic Fever. Jornal Infectious. Diseases. 2008;197:1459-1467. http://jid.oxfordjournals.org/content/ 197/10/1459.long (accessed 14 September 2013).

[61] Cardozo DM, Guelsin GA, Clementino SL, et al. Extração de DNA a partir de sangue humano coagulado para aplicação nas técnicas de genotipagem de antígenos leucocitários humanos e de receptores semelhantes à imunoglobulina. Revista Sociedade Brasileira Medicinal Tropical. 2009;42:651-656. http://www.scielo.br/scielo.php? script=sci_arttext\&pid=S0037-6822009000600008\&lng=en\&nrm=iso\&tlng=en (accessed 14 September 2013).

[62] Alves-Silva M, da Silva Santos PE, Guimarães et al. The ancestry of Brazilian mtDNA lineages. American Journal of Human Genetics. 2000;67:444-461. http:// www.ncbi.nlm.nih.gov/pmc/articles/PMC1287189/ (accessed 12 September 2013).

[63] Carvalho-Silva JDR, Santos FR, Rocha J, and Pena SD. The phylogeography of Brazilian Y-chromosome lineages. American Journal of Human Genetics 2001;68:281-286. http://www.ncbi.nlm.nih.gov/pmc/articles/PMC1234928/ (accessed 10 October 2013).

[64] Nishimura Y, Kamikawaji N, Fujisawa K. et al. Genetic control of immune response and disease susceptibility by HLA-DQ gene. Research Immunology. 1991;142:559-566. http://www.ncbi.nlm.nih.gov/pubmed/1684444 (accessed 01 September 2013).

[65] Huang X, Ling H, Mao W, et al. Association of HLA-A, B, DRB1 alleles and haplotypes with HIV-1 infection in Chongqing, China. BMC Infectious Diseases. 2009;9:201-209. http://www.ncbi.nlm.nih.gov/pmc/articles/PMC2797796/ (accessed 10 September 2013).

[66] Hu J, Li L, Pang L, et al. HLA-DRB1*1501 and HLA-DQB1*0301 alleles are positively associated with HPV16 infection-related Kazakh esophageal squamous cell carcinoma in Xinjiang China. Cancer Immunology Immunotherapy. 2012;61:2135-2141. http://link.springer.com/article/10.1007\%2Fs00262-012-1281-x (accessed 10 September 2013).

[67] Martín JL, Brathwaite O, Zambrano B, et al. The Epidemiology of Dengue in the Americas Over the Last Three Decades: A Worrisome Reality. The American Journal of Tropical Medicine and Hygiene. 2010;82:128-135. http:// www.ncbi.nlm.nih.gov/pmc/articles/PMC2803522/ (accessed 10 September 2013).

[68] Marangon AV, Moliterno RA, Sell AM, et al. Influence of HLA alleles in response to treatment with pegylated interferon-alpha and ribavirin in patients with chronic hep- 
atitis C. International Journal of Immunogenetics. 2012;39:296-302. http://onlinelibrary.wiley.com/doi/10.1111/j.1744-313X.2012.01088.x/abstract (accessed 10 September 2013).

[69] Alagarasu K, Mulay AP, Singh R, Gavade VB, Shah PS, Cecilia D. Association of HLA-DRB1 and TNF genotypes with dengue hemorrhagic fever. Human Immunology. 2013;74:610-617. http://www.sciencedirect.com/science/article/pii/ S0198885913000384 (accessed 01 October 2013).

[70] Falcón-Lezama JA, Ramosa C, Zuñigab J, et al. HLA class I and II polymorphisms in Mexican Mestizo patients with dengue fever. Acta Tropica. 2009;112:193-197. http:// www.sciencedirect.com/science/article/pii/S0001706X09002058 (accessed 01 September 2013).

[71] LaFleur C, Granados J, Alarcon GV, et al. HLA-DR Antigen Frequencies in Mexican Patients with Dengue virus infection: HLA-DR4 as a Possible Genetic Resistance Factor for Dengue Hemorrhagic Fever. Human Immunology. 2002;63:1039-1044. http:// www.sciencedirect.com/science/article/pii/S0198885902006821 (accessed 10 September 2013).

[72] Sierra B, Alegre R, Pérez AB, et al. HLA-A, B, C, and DRB1 allele frequencies in Cuba individuals with antecedents of dengue 2 disease: Advantages of the Cuban population for HLA studies of dengue infection. Human Immunology. 2007;68:531-540. http://www.sciencedirect.com/science/article/pii/S019888590700050X (accessed 11 September 2013).

[73] Alagarasu K, Mulay AP, Sarikhani M, Rashmika D, Shah PS, Cecilia D. Profile of human leukocyte antigen class I alleles in patients with dengue infection from Western India. Hum Immunol. 2013;20:198-8859.

[74] Stephens HAF, Klaythong R, Sirikong M, et al. HLA-A and B allele associations with secondary dengue virus infections correlate with disease severity and the infecting viral serotype in ethnic Thais. Tissue Antigens. 2002;60:309-318. http://www.sciencedirect.com/science/article/pii/S0198885913002292 (accessed 12 September 2013).

[75] Monteiro SP, Brasil PE, Cabello GM, Souza RV, Brasil P, Georg I, Cabello PH, De Castro L. HLA-A*01 allele: a risk factor for dengue haemorrhagic fever in Brazil's population. Mem Inst Oswaldo Cruz. 2012;107:224-30. http://dx.doi.org/10.1590/ S0074-02762012000200012 (accessed 12 September 2013).

[76] Santos BA, Segat L, Dhalia R, et al. MBL2 Gene polymorphisms protect against development of thrombocytopenia associated with sever dengue phenotype. Human Immunology. 2008;69:122-128. http://dx.doi.org/10.1016/j.humimm.2008.01.005 (accessed 12 September 2013).

[77] Zivna I, Green S, Vaughn DW, et al. T Cell responses to an HLA-B*07-restricted epitope on the dengue NS3 protein correlate with disease severity. Journal Immunology. 
2002;168:5959-5965. http://www.jimmunol.org/content/168/11/5959.long (accessed 13 September 2013).

[78] Lan NTP and Hirayama K. Host genetic susceptibility to severe dengue infection. Tropical Medicine and Health. 2011;39:73-81. http://www.ncbi.nlm.nih.gov/pmc/articles/PMC3317601/ (accessed 14 September 2013).

[79] Berenguer M, Lopez-Labrador FX, Wright TL. Hepatitis C and liver transplantation. J Hepatol. 2001;35:666-78. http://www.sciencedirect.com/science/article/pii/ S221074011100146X (accessed 20 September 2013).

[80] Thomson BJ, Finch RG. Hepatitis C virus infection. Clin Microbiol Infect. 2005;11:8694. http://onlinelibrary.wiley.com/doi/10.1111/j.1469-0691.2004.01061.x/abstract (accessed 20 October 2013).

[81] Trepo C, Vierling J, Zeytin FN, Gerlich WH. The First Flaviviridae Symposium. Intervirol. 1997;40:279-88. http://www.ncbi.nlm.nih.gov/pubmed/9612731 (accessed 10 September 2013).

[82] Villano SA, Vlahov D, Nelson KE, Cohn S, Thomas DL. Persistence of viremia and the importance of long-term follow-up after acute hepatitis $\mathrm{C}$ infection. Hepatology. 1999;29:908-914. http://www.ncbi.nlm.nih.gov/pubmed/10051497 (accessed 13 September 2013).

[83] Thomas DL, Seef LB. Natural history of hepatitis C. Clin Liver Dis 2005;9:383- 398. http://dx.doi.org/10.1016/j.cld.2005.05.003

[84] Goodman ZD, Ishak KG. Histopathology of hepatitis C virus infection. Semin Liver Dis 1995;15: 70 - 81. DOI: 10.1055/s-2007-1007264.

[85] NIH Consensus Statement On Management Of Hepatitis C, NIH Consens State Sci Statements 2002;19:1-46.

[86] Freeman AJ, Dore GJ, Law MG, et al. Estimating progression to cirrhosis in chronic hepatitis C virus infection. Hepatology 2001;34:809-816. DOI: 10/ S0270-9139(01)33319-0.

[87] Kobayashi M, Tanaka E, Sodeyama T, Urushihara A, Matsumoto A, Kiyosawa K. The natural course of chronic hepatitis $\mathrm{C}$ : a comparison between patients with genotypes 1 and 2 hepatitis C viruses. Hepatology 1996;23:695-699. DOI: 10/ S0270-9139(96)00112-7.

[88] Mallat A, Hezode C, Lotersztajn S. Environmental factors as disease accelerators during chronic hepatitis C. J Hepatol 2008;48:657-665. http://www.journal-of-hepatology.eu/article/S0168-8278(08)00049-4/abstract (accessed 14 October 2013).

[89] Poynard T, Bedossa P, Opolon P. Natural History Of Liver Fibrosis Progression In Patients With Chronic Hepatitis C. The Obsvirc, Metavir, Clinivir, and Dosvirc groups. Lancet. 1997;349:825-832. doi:10.1016/S0140-6736(96)07642-8. 
[90] Aikawa T, Kojima M, Onishi H, Tamura R, Fukuda S, Suzuki T, Tsuda F, Okamoto H, Miyakawa Y. \& other authors. HLA DRB1 and DQB1 alleles and haplotypes influencing the progression of hepatitis C. J Med Virol. 1996;49,274-278.

[91] Hohler T, Gerken G, Notghi A, Knolle P, Lubjuhn R, Taheri H, Schneider P. M., Meyer zum Buschenfelde KH \& Rittner C. MHC class II genes influence the susceptibility to chronic active hepatitis C. J Hepatol. 1997;27,259-264. http://www.journal-of-hepatology.eu/article/S0168-8278(97)80169-9/abstract (accessed 29 September 2013).

[92] Alric, M. Fort, J. Izopet et al. Genes of the major histocompatibility complex class II influence the outcome of hepatitis C virus infection. Gastroenterology. 1997;113:1675-1681. http://www.gastrojournal.org/article/S0016-5085(97)00536-2/ abstract?referrer=http://www.ncbi.nlm.nih.gov/pubmed/9352872 (accessed 10 September 2013).

[93] Kuzushita N, Hayashi N, Moribe T,Katayama K, Kanto T, Nakatani S, Kaneshige K, Tatsumi T, Ito A, Mochizuki K, Sasaki Y, Kasahara A, Hori M. Influence of HLA haplotypes on the clinical courses of individuals infected with hepatitis $\mathrm{C}$ virus. Hepatol. 1998;27:240-244. DOI: 10/S0270913998000354.

[94] Alric L, Izopet J, Fort M, Vinel JP, Fontenelle P, Orfila C, Payen JL, Sandres K, Desmorat H, Charlet JP, Duffaut M, Abbal M. Study of the association between major histocompatibility complex class II genes and the response to interferon alpha in patients with chronic hepatitis C infection. Hum Immunol. 1999;60:516-23. http:// dx.doi.org/10.1016/S0198-8859(99)00021-X (accessed 10 September 2013).

[95] Asti M, Martinetti M, Zavaglia C, Cuccia MC, Gusberti L, Tinelli C, Cividini A, Bruno S, Salvaneschi L, Ideo G, Mondelli MU, Silini ME. Human leukocyte antigen class II and III alleles and severity of Hepatitis C Virus-Related chronic liver disease. Hepatol. 1999;1272-1279. DOI: 10/S0270913999001937.

[96] Renou C, Halfon P, Pol S, et al. Histological Features And HLA Class II Alleles In Hepatitis C Virus Chronically Infected Patients With Persistently Normal Alanine Aminotransferase Levels. Gut. 2002;51:585-590. http://www.ncbi.nlm.nih.gov/pmc/ articles/PMC1773404/ (accessed 10 September 2013).

[97] Thursz M, Yallop R, Goldin R et al. Influence of MHC class II genotype on outcome of infection with hepatitis C virus. Lancet 1999; 354: 2119-2124.

[98] Fanning LJ, Levis J, Kenny-Walsh E, Wynne F, Whelton M, Shanahan F. 2000. Viral Clearance In Hepatitis C (1b) Infection: Relationship With Human Leukocyte Antigen Class II In a Homogeneous Population. Hepatol 31:1334-1337.

[99] Vejbaesya S, Songsivilai S, Tanwandee T, Rachaibun S, Chantangpol R, Dharakul T. HLA association with hepatitis C virus infection. Hum Immunol 2000; 61: 348-353.

[100] Harcourt G, Hellier S, Bunce M, Satsangi J, Collier J, Chapman R, Phillips R \& Klenerman P. Effect of HLA Class II genotype on T Helper lymphocyte responses and 
viral control in Hepatitis C virus infection. J Viral Hepatitis. 2001;8,174-9. DOI: 10.1046/j.1365-2893.2001.00289.x. (accessed 22 October 2013).

[101] Thio CL, Thomas DL, Goedert JL, et al. Racial differences in HLA class II associations with hepatitis C virus outcomes. J Infect Dis 2001; 184: 16-21. http://jid.oxfordjournals.org/content/184/1/16.long (accessed 22 October 2013).

[102] Kryczka W, Brojer E, Kalinska A, et al. DRB1 alleles in relation to severity of liver disease in patients with chronic hepatitis C. Med Sci Monit 2001;7(Suppl 1):217-220.

[103] Hue S, Cacoub P, Renou C, et al. Human leukocyte antigen class ii alleles may contribute to the severity of hepatitis $C$ virus-related liver disease. J Infect Dis. 2002;186:106-9. http://jid.oxfordjournals.org/content/186/1/106.long (accessed 15 September 2013).

[104] Yenigun A, Belma Durupinar. Decreased frequency of the HLA-DRB1*11 allele in patients with chronic hepatitis C virus infection. J Virol. 2002;76:1787-9. http:// www.ncbi.nlm.nih.gov/pmc/articles/PMC135873/ (accessed 23 September 2013).

[105] Renou C, Halfon P, Pol S, et al. Histological Features And HLA Class II Alleles In Hepatitis C Virus Chronically Infected Patients With Persistently Normal Alanine Aminotransferase Levels. Gut. 2002;51:585-90. http://www.ncbi.nlm.nih.gov/pmc/ articles/PMC1773404/ (accessed 10 September 2013).

[106] Scotto G, Fazio V, D'Allessandro G, et al. Association between HLA class II antigens and hepatitis C virus infection. J Biol Regul Homeost Agents 2003;17(4):316-321.

[107] Yoshizawa K, Ota M, Saito S, et al. Long-term follow-up of hepatitis C virus infection: HLA class II loci influences the natural history of the disease. Tissue Antigens 2003;61(2):159-165.

[108] Yu ML, Dai CY, Chen SC, Chiu CC, Lee LP, Lin ZY, Hsieh MY, Wang LY, Chuang WL \& Chang WY. Human leukocyte antigen class I and II alleles and response to interferon-alpha treatment, in Taiwanese patients with chronic hepatitis $C$ virus infection. J Infect Dis. 2003;188:62-5. http://jid.oxfordjournals.org/content/188/1/62.long (accessed 13 September 2013).

[109] Mckiernan SM, Hagan R, Curry M, MCDonald JSA, Nolan N, Crowley J, Hegarty J, Lawlor E, Kelleher, D. The MHC is a major determinant of viral status, but not fibrotic stage, in individuals infected with Hepatitis C. Gastroenterology. 2000; 118:1124-1130.

[110] Jiao J, \& Wang JB. Hepatitis C virus genotypes, HLADRB alleles and their response to interferon-alfa and ribavirin in patients with chronic hepatitis C. Hepatobiliary and Pancreatic Diseases International. 2005; 4:80-83.

[111] Yoon SK, Han JY, Pyo C-W, et al. Association between human leukocytes antigen alleles and chronic hepatitis $C$ virus infection in the Korean population. Liver Int. 2005;25:1122-7. DOI: 10.1111/j.1478-3231.2005.01105.x. 
[112] Wang LY, Lin HH, Lee TD, Wu YF, Hu CT, Cheng ML, Lo SY. Human leukocyte antigen phenotypes and hepatitis C viral load. J Clin Virol 2005; 32: 144-150.

[113] Ksiaa L, Ayed-Jendoubi S, Sfar I, Gorgi Y, Najjar HAT, Abdallah TB, Ayed K. Viral Immunology. June 2007, 20(2): 312-9. doi:10.1089/vim.2006.0060.

[114] Cursino-Santos JR, Donadi EA, Martinelli AL, Louzada-Junior P, Martinez-Rossi NM. Evolution of hepatitis $C$ virus infection under host factor influence in an ethnically complex population. Liver Int. 2007;27(10):1371-8. http://onlinelibrary.wiley.com/doi/10.1111/j.1478-3231.2007.01600.x/abstract (accessed 10September 2013).

[115] Harris RA, Sugimoto K, Kaplan DE, Ikeda F, Kamoun F, Chang KM. Human leukocyte antigen class II associations with hepatitis c virus clearance and virus-specific CD4 $\mathrm{T}$ cell response among caucasians and african americans. Hepatology. 2008;48:70-9. http://www.ncbi.nlm.nih.gov/pmc/articles/PMC2749605/ (accessed 12 September 2013).

[116] El-Chennawi FA, Auf FA, Metwally SS, Mosaad YM, El-Wahab MA, Tawhid ZE. HLA-Class II Alleles in Egyptian Patients with Hepatocellular Carcinoma Immunological Investigations, 2008 37:661-74. doi:10.1080/08820130802111605(accessed 12 September 2013).

[117] Corghi DB, Gonc, ales NSL, Marques SBD, Junior FLG. Distribution of the human leukocyte antigen class II alleles in brazilian patients with chronic hepatitis $\mathrm{C}$ virus infection. Braz J Med Biol Res 2008;41:884-889.

[118] De Almeida BS, Silva GMF, Silva PM, Perez RM, Figueiredo FAF,Porto LC. Ethnicity and route of $\mathrm{HCV}$ infection can influence the associations of HLA with viral clearance in an ethnically heterogeneous population Journal of Viral Hepatitis, 2011, 18, 692-9 doi:10.1111/j.1365-2893.2010.01429.x. (accessed 12 September 2013).

[119] Cangussu LOF,Teixeira R,Campos EF, Rampim GF, Mingoti SA, Martins-Filho OAM. Gerbase-DeLima. HLA Class II Alleles and Chronic Hepatitis C Virus Infection Clinical Immunology.282-7 doi: 10.1111/j.1365-3083.2011.02568.x

[120] De Rueda PM, Lo pez-Nevot MA, Saenz-Lopez P, Casado J, Martın-casares A, Palomares P. et al. Importance of host genetic factors HLA and IL28B as predictors of response to pegylates interferon and ribavirin. American Journal of Gastroenterology. 2011;106:1246-54. http://www.nature.com/ajg/journal/v106/n7/full/ajg201182a.html (accessed 23 September 2013).

[121] Marangon AV, Silva GF, de Moraes CF, Grotto RM, Pardini MI, de Pauli DS, Visentainer JE, Sell AM, Moliterno RA. Protective effect of HLA-DRB1 11 and predisposition of HLA-C 04 in the development of severe liver damage in Brazilian patients with chronic hepatitis C virus infection. Scand J Immunol. 2012;76:440-7. http://onlinelibrary.wiley.com/doi/10.1111/j.1365-3083.2012.02755.x/abstract (accessed 22 September 2013). 
[122] Ali L, Mansoor A, Ahmad N, Siddiqi S, Mazhar K, Muazzam AG, Qamar R, KhanKM. Patient HLA-DRB1* and -DQB1* allele and haplotype association with hepatitis C virus persistence and clearance. J Gen Virol. 2010;91:1931-8. http:// vir.sgmjournals.org/content/91/8/1931.long (accessed 12 October 2013).

[123] Shaker O, Bassiony H, Raziky ME, El-Kamary SS, Esmat G, El-Ghor S, Mohamed MM. Human Leukocyte Antigen Class II Alleles (DQB1 and DRB1) as Predictors for Response to InterferonTherapy in HCV Genotype 4 Hindawi Publishing Corporation Mediators of Inflammation. 2013, Article ID 392746, 10 pageshttp://dx.doi.org/ $10.1155 / 2013 / 392746$.

[124] Yee LJ. Host genetic determinants in Hepatitis C virus infection. Genes Immun. 2004; 5, 237-45. http://www.nature.com/gene/journal/v5/n4/full/6364090a.html (accessed 23 September 2013).

[125] Tillmann HL, Chen D-F, Trautwein C, Kliem V, Grundey A, Berning-Haag A, Boker K, Kubicka S, Pastucha L, Stangel W, \& Manns M. Low frequency of HLA-DRB1*11 in hepatitis C virus induced end stage liver disease. Gut. 2001;48,714-8 http:// www.ncbi.nlm.nih.gov/pmc/articles/PMC1728277/ (accessed 15 September 2013).

[126] Hong X, Yu RB, Sun NX, Wang B, Xu YC, Wu GL. Human leukocyte antigen class II DQB1 $^{*} 0301$, DRB1 $^{*} 1101$ alleles and spontaneous clearance of hepatitis $C$ virus infection: a meta-analysis. World J Gastroenterol. 2005;11:7302-7. http://www.wjgnet.com/ 1007-9327/full/v11/i46/7302.htm (accessed 12 September 2013).

[127] Patel K, Norris S, Lebeck L, et al. HLA class I allelic diversity and progression of fibrosis in patients with chronic hepatitis C. Hepatology. 2006;2:241-6. http://onlinelibrary.wiley.com/doi/10.1002/hep.21040/abstract (accessed 10 September 2013).

[128] López-Vázquez A, Rodrigo L, Mina-Blanco A, et al. Extended human leukocyte antigen haplotype EH18.1 influences progression to hepatocellular carcinoma in patients with hepatitis C virus infection. J Infect Dis. 2004;189:957-63. http://jid.oxfordjournals.org/content/189/6/957.long (accessed 12 September 2013).

[129] Ivić I, Bradarić N, Puizina-Ivić N, Ledina D, Lukšić B, \& Martinić R. Hla-Cw7 Allele as Predictor of favorable therapeutic response to Interferon- $\alpha$ in Patients with Chronic Hepatitis C. Croat Med J. 2007;48:807-13. http://www.ncbi.nlm.nih.gov/pmc/articles/PMC2213809/ (accessed 12 September 2013).

[130] Miyaguchi S, Saito H, Ebinuma H, Morizane T \& Ishii H. Possible association between HLA antigens and the response to interferon in Japanese patients with chronic hepatitis C. Tissue Antigens. 1997; 49, 605-611.

[131] Dai C-Y, Chuang W-L, Hsieh M-Y, Huang JF, Lin Y-Y, Chu P-Y, Hou NJ, Lin ZY, Chen SC, Hsieh MY, Wang LY \& Yu ML. Human leukocyte antigen alleles and the response to pegylated interferon/ribavirin therapy in chronic hepatitis $\mathrm{C}$ patients. Antiviral Res. 2010;85:396-402. http://www.sciencedirect.com/science/article/pii/ S016635420900535X (accessed 16 September 2013). 
[132] Rhodes SL, Erlich H, Im KA, Wang J, Li J, Bugawan T, Jeffers L, Tong X, Su X, Rosen HR, Yee LJ, Liang TJ, Yang H. Associations between the human MHC and sustained virologic response in the treatment of chronic hepatitis $C$ virus infection. Genes Immun 2008; 9, 328-33. http://www.ncbi.nlm.nih.gov/pmc/articles/PMC2696808/ (accessed 12 September 2013).

[133] McMahon BJ.Chronic hepatitis B virus infection.Med Clin North Am. 2014;98(1): 39-54. doi: 10.1016/j.mcna.2013.08.004.(accessed 12 September 2013).

[134] Lai CL, Ratziu V, Yuen MF, Poynard T. Viral hepatitis B. Lancet 2003; 362: 2089-94.

[135] Tamori A, Kawada N. HLA class II associated with outcomes of hepatitis B and C infections. World J Gastroenterol. 2013;19:5395-401. http:// www.ncbi.nlm.nih.gov/pmc/articles/PMC3761092/ (accessed 12 September 2013).

[136] Nishida N, Sawai H, Matsuura K, Sugiyama M, Ahn SH, Park JY, et al. Genome-wide association study confirming association of HLA-DP with protection against chronic hepatitis B and viral clearance in Japanese and Korean. PLoS One. 2012;7(6):e39175. doi: 10.1371/journal.pone.0039175 accessed 12 September 2013).

[137] Mbarek H, Ochi H, Urabe Y, Kumar V, Kubo M, Hosono N, Takahashi A, Kamatani Y, Miki D, Abe H, Tsunoda T, Kamatani N, Chayama K, Nakamura Y, Matsuda K. A genomewide association study of chronic hepatitis B identified novel risk locus in a Japanese population. Hum Mol Genet 2011; 20: 3884-92. http://hmg.oxfordjournals.org/content/20/19/3884.long (accessed 12 October 2013).

[138] Buchbinder SP, Katz MH, Hessol NA, O'Malley PM, Holmberg SD. Long-term HIV-1 infection without immunologic progression. AIDS. 1994;8:1123- 8. http:// www.ncbi.nlm.nih.gov/pubmed/7986410 (accessed 12 September 2013).

[139] Kaslow RA, Carrington M, Apple R, Park L, Munoz A, Saah AJ, et al. Influence of combinations of human major histocompatibility complex genes on the course of HIV-1 infection. Nat. Med. 1996;2:405-411.

[140] Tang J, Cormier E, Gilmour J, Price MA, Prentice HA, Song W, Kamali A, Karita E, Lakhi S, Sanders EJ, Anzala O, Amornkul PN, Allen S, Hunter E, Kaslow RA. Human leukocyte antigen variants $B^{*} 44$ and $B^{*} 57$ are consistently favorable during two distinct phases of primary HIV-1 infection in sub-Saharan Africans with several viral subtypes. J.Virol. 2011;85:8894-902. http://www.ncbi.nlm.nih.gov/pmc/articles/ PMC3165830/ (accessed 12 September 2013).

[141] Zhang W, Wang L, Hong K, Liu Y, Su B, Xu C, Xu J, Ruan Y, Shao Y, Zheng D. Frequency of HLA-A*03 associates with HIV-1 infection in a Chinese cohort. Sci China Life Sci. 2013.1404-9. http://link.springer.com/article/10.1007\%2Fs11427-013-4555-4 (accessed 21 September 2013).

[142] Lazaryan A, Song W, Lobashevsky E, Tang J, Shrestha S, Zhang K, McNicholl JM, Gardner LI, Wilson CM, Klein RS, Rompalo A, Mayer K, Sobel J, Kaslow RA. The influence of human leukocyte antigen class I alleles and their population frequencies 
on human immunodeficiency virus type 1 control among African Americans. Hum. Immunol. 2011;72:312-8. http://www.ncbi.nlm.nih.gov/pmc/articles/PMC3778654/ (accessed 20 September 2013).

[143] Pereyra F, Jia X, McLaren PJ, Telenti A, de Bakker PI, Walker BD, Ripke S, Brumme CJ, Pulit SL, Carrington M, et al. International HIV Controllers Study. The major genetic determinants of HIV-1 control affect HLA class I peptide presentation. Science. 2010;330:1551-7. http://www.ncbi.nlm.nih.gov/pmc/articles/PMC3235490/ (accessed 10 September 2013).

[144] Honeyborne I, Prendergast A, Pereyra F, Leslie A, Crawford H, Payne R, Reddy S, Bishop K, Moodley E, Nair K, et al. Control of human immunodeficiency virus type 1 is associated with HLA-B* 13 and targeting of multiple gag-specific CD8+ T-cell epitopes. J. Virol. 2007;81:3667-3672. http://www.ncbi.nlm.nih.gov/pmc/articles/ PMC1866034/ (accessed 10 September 2013).

[145] Fellay J, Ge D, Shianna KV, Colombo S, Ledergerber B, Cirulli ET, Urban TJ, Zhang $\mathrm{K}$, Gumbs CE, Smith JP, et al; NIAID Center for HIV/AIDS Vaccine Immunology (CHAVI). Common genetic variation and the control of HIV-1 in humans. PLoS Genet. 2009;5:e1000791. http://www.ncbi.nlm.nih.gov/pmc/articles/PMC2791220/ (accessed 10 September 2013).

[146] Kiepiela P, Leslie AJ, Honeyborne I, Ramduth D, Thobakgale C, Chetty S, Rathnavalu P, Moore C, Pfafferott KJ, Hilton L, et al. Dominant influence of HLA-B in mediating the potential co-volution of HIV and HLA. Nature. 2004;432:769-75. http:// www.nature.com/nature/journal/v432/n7018/full/nature03113.html (accessed 10 September 2013).

[147] Lazaryan A, Lobashevsky E, Mulenga J, Karita E, Allen S, Tang J, and Kaslow RA. Human leukocyte antigen B58 supertype and human immunodeficiency virus type 1 infection in native Africans. J. Virol. 2006;80:6056-60. http:// www.ncbi.nlm.nih.gov/pmc/articles/PMC1472610/ (Accessed 01 October 2013).

[148] Carlson JM, Listgarten J, Pfeifer N, Tan V, Kadie C, Walker BD, Ndung'u T, Shapiro R, Frater J, Brumme ZL, et al.. Widespread impact of HLA restriction on immune control and escape pathways of HIV-1. J. Virol. 2012;86:5230-43. http:// www.ncbi.nlm.nih.gov/pmc/articles/PMC3347390/ (accessed 20 October 2013).

[149] Migueles SA, Sabbaghian MS, Shupert WL, Bettinotti MP, Marincola FM, Martino L, Hallahan CW, Selig SM, Schwartz D, Sullivan J, and Connors M. HLA B*5701 is highly associated with restriction of virus replication in a subgroup of HIV-infected long term nonprogressors. Proc. Natl. Acad. Sci. 2000;97:2709-14. http:// www.ncbi.nlm.nih.gov/pmc/articles/PMC15994/ (accessed 14 September 2013).

[150] O'Brien SJ, Gao X, and Carrington M. HLA and AIDS: a cautionary tale. Trends Mol.Med. 2001;7: 379-81. doi:10.1016/S1471-4914(01)02131-1.

[151] Leslie A, Matthews PC, Listgarten J, Carlson JM, Kadie C, Ndung'u T, Brander C, Coovadia H, Walker BD, Heckerman D, and Goulder, PJ. Additive contribution of 
HLA class I alleles in the immune control of HIV-1 infection. J. Virol. 2010;84:987988. http://www.ncbi.nlm.nih.gov/pmc/articles/PMC2937780/ (accessed 20 September 2013).

[152] Lécuroux C, Sáez-Cirión A, Girault I, Versmisse P, Boufassa F, Avettand-Fenoël V, Rouzioux C, Meyer L, Pancino G, Lambotte O, Sinet M, Venet A. Both HLA-B*57 and plasma HIV RNA levels 1 contribute to the HIV-specific CD8+T cell response in HIV controllers. J. Virol. 2013; doi:10.1128/JVI.02098-13.

[153] Gao X, Nelson GW, Karacki P, Martin MP, Phair J, Kaslow R, Goedert, J.J., Buchbinder, S., Hoots, K., Vlahov, D, et al. Effect of a single amino acid change in MHC class I molecules on the rate of progression to AIDS. N.Engl. J. Med. 2001;344:1668-75. http://www.nejm.org/doi/full/10.1056/NEJM200105313442203 (accessed 10 October2013).

[154] Honeyborne I, Codoner FM, Leslie A et al. HLA-Cw*03-restricted CD8+ T-cell responses targeting the HIV-1 gag major homology region drive virus immune escape and fitness constraints compensated for by intracodon variation. J Virol. 2010;84:11279-88. http://www.ncbi.nlm.nih.gov/pmc/articles/PMC2953179/ (accessed 20 September 2013).

[155] Honda K, Zheng N, Murakoshi H et al. Selection of escape mutant by HLC-C-restricted HIV-1 Pol-specific cytotoxic T lymphocytes carrying strong ability to suppress HIV-1 replication. Eur J Immunol. 2011;41:97-106. DOI: 10.1002/eji.201040841.

[156] Marangon AV, Guelsin GAS, Visentainer JEL, Borelli SD, Watanabe MAE, Consolaro MEL, KRC Ferracioli, Rudnick CCC and Sell AM. The Association of the Immune Response Genes to Human Papillomavirus-Related Cervical Disease in a Brazilian Population. Biomed Res Int. 2013;2013:1-11. http://www.ncbi.nlm.nih.gov/pmc/articles/ PMC3722781/ (accessed 23 September 2013).

[157] Silva SB, Granados J, Gorodezky C, Aláez C, Aguilar HF, Flores RMC, González GG,LDV Chapa, Casas JM, Guerrero JFG and Saldaña HAB. HLA-DRB1 Class II antigen level alleles are associated with persistent HPV infection in Mexican women; a pilot study. Infectious Agents and Cancer. 2013;8:31. http:// www.ncbi.nlm.nih.gov/pmc/articles/PMC3766142/ (accessed 30 September 2013).

[158] Peng S, Trimble C, Wu L, Pardoll D, Roden R, Hung CF, Wu TC. HLA-DQB1*02-restricted HPV-16 E7 peptide-specific CD4+ T-cell immune responses correlate with regression of HPV-16-associated high-grade squamous intraepithelial lesions. Clin Cancer Res 2007, 13(8):2479-87, Wank R, Thomssen C: High risk of squamous cell carcinoma of the cervix for women with HLA-DQw3. Nature. 1991;352:723-5. http:// www.ncbi.nlm.nih.gov/pmc/articles/PMC3181117/ (accessed 10 September 2013).

[159] Apple RJ, Becker TM, Wheeler CM, Erlich HA. Comparison of human leukocyte antigen DR-DQ disease associations found with cervical dysplasia and invasive cervical 
carcinoma. J Natl Cancer Inst. 1995;87:427-36. http://jnci.oxfordjournals.org/content/ 87/6/427.long (Accessed 10 September 2013).

[160] Ferrera A, Olivo A, Alaez C, Melchers WJ, Gorodezky C. HLA DOA1 and DOB1 loci in Honduran women with cervical dysplasia and invasive cervical carcinoma and their relationship to human papillomavirus infection. Hum Biol. 1999;71:367-379. http://digitalcommons.wayne.edu/humbiol/vol71/iss3/5/ (accessed 03 October 2013).

[161] Lin P, Koutsky LA, Critchlow CW, Apple RJ, Hawes SE, Hughes JP, Touré P, Dembele A, Kiviat NB. HLA class II DR-DQ and increased risk of cervical cancer among Senegalese women. Cancer Epidemiol Biomarkers Prev. 2001;10:1037-45. http:// cebp.aacrjournals.org/content/10/10/1037.long (accessed 24 October 2013).

[162] Madeleine MM, Brumback B, Cushing-Haugen KL, Schwartz SM, Daling JR, Smith AG, Nelson JL, Porter P, Shera KA, McDougall JK, Galloway DA. Human leukocyte antigen class II and cervical cancer risk: a population-based study. J Infect Dis. 2002;186:1565-74. http://jid.oxfordjournals.org/content/186/11/1565.long (accessed 20 September 2013).

[163] Cuzick J, Terry G, Ho L, Monaghan J, Lopes A, Clarkson P, Duncan I. Association between high-risk HPV types, HLA DRB1* and DQB1* alleles and cervical cancer in British women. Br J Cancer. 2000;82:1348-52. http://www.ncbi.nlm.nih.gov/pmc/articles/PMC2374489/ (accessed 27 October 2013).

[164] Metcalfe S, Roger M, Faucher MC, Coutlée F, Franco EL, Brassard P. The association between human leukocyte antigen (HLA)-G polymorphisms and human papilloma virus (HPV) infection in Inuit women of northern Quebec. Hum Immunol. 2013;74(12):1610-1615.

[165] Song EY, Shin S, Park KU, Park MH, Sung MW, Kim KH, Kwon TK. Associations of HLA-DRB1 and -DQB1 alleles with severe recurrent respiratory papillomatosis in Korean patients. Hum Immunol. 2013;74:961-4. http://www.sciencedirect.com/ science/article/pii/S0198885913001067 (accessed 23 September 2013).

[166] Zhao M, Qiu L, Tao N, Zhang L, Wu X, She Q, Zeng F, Wang Y, Wei S, Wu X. HLA DRB allele polymorphisms and risk of cervical cancer associated with human papillomavirus infection: a population study in China. Eur J Gynaecol Oncol. 2013;34:54-9.

[167] Macedo AM, Pena SDJ. Genetic Variability of Trypanosoma cruzi: implications for the pathogenesis of Chagas disease. Parasitol Today. 1998;14:119-124.

[168] Chagas C. Nova tripanozomiaze humana. Estudos sobre a morfologia e o ciclo evolutivo do Schizotrypanum cruzi n. gen., n. sp. Agente etiológico de uma nova entidade mórbida para o homem. Mem Inst Oswaldo Cruz. 1909;1:59-218. http://www.sciencedirect.com/science/article/pii/S0001706X05002500 (accessed 25 October 2013).

[169] Köberle F. 50 Years of Chagas' disease. Munch Med Wochenschr 1957;99 1193-1198. 
[170] Moncayo A, Ortiz Yanine MI. An update Chagas disease (human American trypanosomiasais). Ann Trop Med Parasitol. 2006;100:663-677. http://dx.doi.org/ $10.1179 / 136485906$ X112248.

[171] Coura JR. Chagas disease: what is known and what is needed - a background article.Mem Inst Oswaldo Cruz 2007;102:113-122. http://dx.doi.org/10.1590/ S0074-02762007000900018.

[172] Silva LJ. A evolução da doença de Chagas no Estado de São Paulo. São Paulo: Editora Hucitec; 1999. http://dx.doi.org/10.1590/S0102-311X2003000400019.

[173] Dutra WO, Gollob KJ. Current concepts in immunoregulation and pathology of human Chagas disease. Curr Opin Infec Dis. 2008;21:287-292. http:// www.ncbi.nlm.nih.gov/pmc/articles/PMC3322114/ (accessed 23 September 2013).

[174] Barrett MP, Burchmore RJ, Stich A, et al. The trypanosomiases Lancet 2003;362:1469-480. doi:10.1016/S0140-6736(03)14694-6.

[175] Brener Z. Pathogenesis and immunopathology of chronic Chagas disease. Mem Inst Oswaldo Cruz 1987;82: 205-213.

[176] Moncayo A, Silveira AC. Current epidemiological trends for Chagas disease in Latin America and future challenges in epidemiology, surveillance and health policy. Mem Inst Oswaldo Cruz 2009;104:31-40. http://dx.doi.org/10.1590/ S0074-02762009000900005.

[177] Coura JR, Vinãs PA. Chagas disease: a new worldwide challenge. Nature 2010;465:S6-S7. http://www.nature.com/nature/journal/v465/n7301_supp/full/ nature09221.html (accessed 23 September 2013).

[178] Moolani Y, Bukhman G, Hotez PJ. Neglected Tropical Diseases as Hidden Causes of Cardiovascular Disease. PLoS Negl Trop Dis. 2012;6:e1499.

[179] Dias E, Laranja FS, Miranda A, et al. Chagas disease. A clinical, epidemiologic and pathologic study. Circulation 1956;14:1035-1060. http://www.ncbi.nlm.nih.gov/pmc/ articles/PMC3383757/ (accessed 20 October 2013).

[180] Dutra WO, Martins-Filho OA, Cançado JR. Activated T and B lymphocytes in peripheral blood of patients with Chagas disease. Int Immunol. 1994;6:499-506.

[181] Dutra WO, Martins-Filho OA, Cançado JR. et al. Chagasic patients lack CD28 expression on many of their circulating T lymphocytes. Scand J Immunol. 1996;43:88-93.

[182] Tarleton RL. Trypanosoma cruzi- induced suppression of IL-12 production. II. Evidence for a role for suppressor cells. J Immunol. 1988;140:2769-2773. http:// www.jimmunol.org/content/140/8/2769.long (accessed 10 September 2013).

[183] Tarleton RL, Grusky MJ, Postan M, et al. Trypanosoma cruzi infection in MHC-deficient mice: further evidence for the role of both class I- and class II-restricted T cells 
in immune resistance and disease. Int Immunol. 1996;8:13-22. http://intimm.oxfordjournals.org/content/8/1/13.long (accessed 10 October 2013).

[184] Clark RK, Kuhn RE. Trypanosoma cruzi does not induce apoptosis in murine fibroblasts. Parasitology. 1999;118:167-75.

[185] Corrêa-Oliveira R, Gomes JAS, Lemos EM, et al. The Role of the Immune Response on the Development of Severe Clinical Forms of Human Chagas Disease. Mem Inst Oswaldo Cruz. 1999; 94:253-255. http://dx.doi.org/10.1590/S0074-02761999000700042.

[186] Dutra WO, Colley DG, Pinto-Dias JC, et al. Self and nonself stimulatory molecules induce preferential expansion of CD5C B cells or activated T cells chagasic patients, respectively. Scand J Immunol. 2000;51:91-97. http://onlinelibrary.wiley.com/doi/ 10.1046/j.1365-3083.2000.00648.x/abstract (accessed 20 September 2013).

[187] d'Avila Reis D, Lemos EM, Silva GC, et al. Phenotypic characterization of the inflammatory cells in chagasic megaoesophagus. Trans R Soc Trop Med Hyg. 2001;95:177178.

[188] Cardoso GM, Morato MJ, Gomes JA. Comparative analysis of cell phenotypes in different severe clinical forms of Chagas' disease. Front Biosci. 2006;11:1158-1163.http:// www.bioscience.org/2006/v11/af/1870/fulltext.htm (accessed 13 September 2013).

[189] da Silveira AB, Adad SJ, Correa-Oliveira R, et al. Morphometric study of eosinophils, mast cells, macrophages and fibrosis in the colon of chronic chagasic patients with and without megacolon. Parasitology 2007;134:789-796. DOI: http://dx.doi.org/ 10.1017/S0031182007002296.

[190] Mack DG, Jonhson JJ, Roberts F, et al. HLA-classe II genes modify outcome of Toxoplasma gondii infection. Int J Parasitol. 1999;29:1351-1358. http://www.sciencedirect.com/science/article/pii/S0020751999001526 (accessed 20 September 2013).

[191] Acquatella H, Catalioti F, Gómez JR, et al. Asociación entre HLA-DB9 y Enfermedad de Chagas. In Rodríguez-Lemoine V, editor. Genética: VI Congreso Latinoamericano de Genética. Venezuela: Ars. Gráfica S.A; 1984

[192] Fernandez-Mestre MT, Layrisse Z, Montagnani S, et al. Influence of the HLA class II polymorphism in chronic Chagas' disease. Parasite Immunol. 1998;20:197-203.

[193] Deghaide NH, Dantas RO, Donadi EA. HLA Class I and II Profiles of Patients Presenting with Chagas' Disease. Dig Dis Sci. 1998;43:246-252.

[194] Dalalio MMO, Visentainer JEL, Moliterno RA, et al. Association of HLA-DR2 with chronic Chagasic cardiopathy in a population at Paraná Northeast region, Brazil. Acta Scientiarum. 2002;24:727-730.

[195] Cruz-Robles D, Reyes PA, Monteón-Padilla VM, et al. MHC Class I and Class II Genes in Mexican Patients With Chagas Disease. Hum Immunol. 2004;65:60-65. 
http://www.sciencedirect.com/science/article/pii/S0198885903006360 (accessed 23 October 2013).

[196] García Borrás S, Diez C, Cotorruelo C, et al. HLA class II DRB1 polymorphism in Argentinians undergoing chronic Trypanosoma cruzi infection. Ann Clin Biochem. 2006;43:214-216. http://acb.sagepub.com/content/43/3/214.long (accessed 03 October 2013).

[197] García-Borrás S, Racca L, Cotorruelo C, et al. Distribution of HLA-DRB1 alleles in Argentinean patients with Chagas' disease cardiomyopathy. Imunol Invest. 2009;38:268-275.

[198] Nieto A, Beraún Y, Collado MD, et al. HLA haplotypes are associated with differential susceptibility to Trypanosoma cruzi infection. Tissue Antigens. 2000;55:195-198. http://onlinelibrary.wiley.com/doi/10.1034/j.1399-0039.2000.550301.x/abstract ～(accessed 20 September 2013).

[199] del Puerto F, Nishizawa JE, Kikuchi M, et al. Protective Human Leucocyte Antigen Haplotype, HLA-DRB1*01-B*14, against Chronic Chagas Disease in Bolivia PLoS Negl Trop Dis. 2012;6:e1587. http://www.ncbi.nlm.nih.gov/pmc/articles/ PMC3308929/ (accessed 20 October 2013).

[200] Llop E, Rothhammer F, Acuña M, et al. HLA antigens in cardiomyopathic Chilean chagasics. Am J Hum Genet.1988;43:770-773. http://www.ncbi.nlm.nih.gov/pmc/articles/PMC1715553/ (accessed 04 October 2013).

[201] Llop E, Rothhammer F, Acuña M, et al. HLA antigens in Chagas cardiomyopathy:new evidence based on a case control study. Rev Med Chil. 1991;119:633-636.

[202] Layrisse Z, Fernandez MT, Montagnani S, et al. HLA-C $\left(^{*}\right) 03$ is a risk factor for cardiomyopathy in Chagas disease. Hum Immunol. 2000;61:925-92.

[203] Sierp GM, Albert ED. Analysis of the HLA data of the 5th Latin American Histocompatibility Workshop. In: Gorodezky C, Sierp G, Albert E (ed) Immunogenetics Laboratory. Munich; 1992.

[204] Colorado IA, Acquatella H, Catalioti F, et al. HLA class II DRB1, DQB1, DPB1 polymorphism and cardiomyopathy due to Trypanosoma cruzi chronic infection. Hum Immunol. 2000;61:320-325. http://www.sciencedirect.com/science/article/pii/ S0198885999001779 (accessed 02 October 2013).

[205] Faé KC, Drigo SA, Cunha-Neto E, et al. HLA and beta-myosin heavy chain do not influence susceptibility to Chagas disease cardiomyopathy. Microbes Infect. 2000;2:745-751. http://www.sciencedirect.com/science/article/pii/S1286457900005013 (accessed 03 October 2013).

[206] Groh V, Steinle A, Bauer S, et al. Recognition of stress-induced MHC molecules by intestinal epithelial gammadelta T cells. Science 1998;279:1737-1740. 
[207] Aida K, Juarez S, Kikuchi M, et al. HLA-B35 and MICA-A5 synergistically enhanced susceptibility to Chagas Heart disease. MHC 2000;7:63-70.

[208] Lima-Junior JC, Rodrigues-da-Silva RN, Banic DM, Jiang J, Singh B, Fabrício-Silva GM, Porto LC, Meyer EV, Moreno A, Rodrigues MM, Barnwell JW, Galinski MR, de Oliveira-Ferreira J. Influence of HLA-DRB1 and HLA-DQB1 alleles on IgG antibody response to the P. vivax MSP-1, MSP-3 $\alpha$ and MSP-9 in individuals from Brazilian endemic area. PLoS One. 2012;7(5). http://www.ncbi.nlm.nih.gov/pmc/articles/ PMC3359319/ (accessed 30 September 2013).

[209] Lulli P, Mangano VD, Onori A, Batini C, Luoni G, Sirima BS, Nebie I, Chessa L, Petrarca V, Modiano D. HLA-DRB1 and -DQB1 loci in three west African ethnic groups: genetic relationship with sub-Saharan African and European populations. Hum Immunol. 2009 Nov;70:903-9. http://www.sciencedirect.com/science/article/pii/ S0198885909002006 (accessed 03 October 2013).

[210] Osafo-Addo AD, Koram KA, Oduro AR, Wilson M, Hodgson A, Rogers WO. HLADRB ${ }^{*} 04$ allele is associated with severe malaria in northern Ghana. Am J Trop Med Hyg. 2008 Feb;78:251-5. http://www.ajtmh.org/content/78/2/251.long (accessed 03 September 2013).

[211] Hananantachai H, Patarapotikul J, Ohashi J, Naka I, Looareesuwan S, Tokunaga K.Polymorphisms of the HLA-B and HLA-DRB1 genes in Thai malaria patients. Jpn J Infect Dis. 2005 Feb;58:25-8. http://www0.nih.go.jp/JJID/58/25.html (accessed 04 September 2013).

[212] Shankarkumar U, Devaraj JP, Ghosh K, Karnad D, Anand K, Mohanty D. HLA associations in P. falciparum malaria patients from Mumbai, western India. Indian J Malariol. 2002 Sep-Dec; 39:76-82. 